NBER WORKING PAPER SERIES

\title{
DID MERGERS HELP JAPANESE MEGA-BANKS AVOID FAILURE? ANALYSIS OF THE DISTANCE TO DEFAULT OF BANKS
}

\author{
Kimie Harada \\ Takatoshi Ito \\ Working Paper 14518 \\ http://www.nber.org/papers/w14518
NATIONAL BUREAU OF ECONOMIC RESEARCH
1050 Massachusetts Avenue
Cambridge, MA 02138
December 2008

The paper started as a joint project with Dr. Kelly Wang when she was Assistant Professor at University of Tokyo. The authors are grateful to her for her help in providing us with computer programs and in discussion the ways to apply her methods to the Japanese banking data. Upon Dr. Wang's departure from the University of Tokyo, the project was carried on by the current two authors with full consent from Dr. Wang. The current two authors take responsibility for any remaining errors. Mr. Shuhei Takahashi provided us with superb research assistance. We are grateful for financial support from Nomura foundation for social science and Chuo University for Special Research. We are also grateful for helpful discussions with Masaya Sakuragawa, Naohiko Baba, Satoshi Koibuchi, Woo Joong Kim, Joe Peek, Kazuo Kato and for insigutful comments from participants in Asia pacific Economic Association in Hong Kong in 2007, Japan Economic Association in 2008, NBER Japan Group Meeting in 2008 and Asian FA-NFA 2008 International Conference. The views expressed herein are those of the author(s) and do not necessarily reflect the views of the National Bureau of Economic Research.

NBER working papers are circulated for discussion and comment purposes. They have not been peerreviewed or been subject to the review by the NBER Board of Directors that accompanies official NBER publications.

(C) 2008 by Kimie Harada and Takatoshi Ito. All rights reserved. Short sections of text, not to exceed two paragraphs, may be quoted without explicit permission provided that full credit, including $\odot$ notice, is given to the source. 
Did Mergers Help Japanese Mega-Banks Avoid Failure? Analysis of the Distance to Default of Banks

Kimie Harada and Takatoshi Ito

NBER Working Paper No. 14518

December 2008

JEL No. G19,G21

\begin{abstract}
In the late 1990s, several large Japanese banks failed for the first time in its postwar history. As the financial environment was deteriorating further, several remaining banks decided to merge among themselves, presumably, to make their operations more efficient to avoid failures. This paper defines, calculates and analyzes the distance to default (DD), a concept of credit risk in corporate finance, of Japanese large banks. The DD helps us to answer a question whether mergers in the late 1990s and 2000s made the merged banks financially more robust as intended. The novelty of the paper is to develop a method of analyzing the DD for banks that experience a merger, and to apply the method to the Japanese banking data. Our findings include: (1) A merged bank fundamentally inherits financial soundness of pre-merged banks, without adding special value from the merger. A merger of sound (unsound) banks produced a sound (unsound, respectively) merged financial institution; and (2) In some cases, a merged bank experienced a negative DD right after the merger. The findings are consistent with a view that a primary objective of a merger was to take advantage of the perceived too-big-to-fail policy, rather than to pursue a radical reform. Another interpretation is that mergers with intention of enhancing efficiency resulted in failed implementation of true operational efficiency, such as quick integration of computer operation systems and elimination of duplicating branches.
\end{abstract}

\author{
Kimie Harada \\ Chuo University \\ Graduate School of International Accounting \\ 42-8 Honmura-cho, Ichigaya \\ Shinjuku-ku, Tokyo 162-8473, JAPAN \\ kimieh@tamacc.chuo-u.ac.jp \\ Takatoshi Ito \\ Graduate School of Economics \\ University of Tokyo \\ 7-3-1 Hongo, Bunkyo-ku, Tokyo 113-0033 \\ JAPAN \\ and NBER \\ ITOINTOKYO@aol.com
}




\section{Introduction}

The Japanese banking sector went through tumultuous years from the early 1990s to 2003; first, failures of small to medium-size financial institutions in the first half of 1990s; second, the failures of major institutions in 1997; and another rush of big failures in 2003. It was only since 2005 that Japanese financial institutions have regained financial strength, and the risk of systemic failure has receded. During the difficult years between 1997 and 2003, many banks attempted several methods to enhance their capital bases, as capital was constantly eroded by losses from nonperforming loans (NPLs) and declining stock prices. One way that began to enhance capital was a merger that took advantage of operational synergy and scale economies. In fact, mergers of very large banks took place in Japan, most likely to avert failures due to a lack of capital. The objective of this paper is to evaluate whether a merger during this period indeed helped the involved banks move away from the abyss of failures, or at least so perceived by investors.

Sumitomo Bank and Sakura Bank (formerly known as Mitsui Bank) announced a merger on April 1, 2001. This was quite significant because the two banks were, respectively, the core member of the traditional enterprise groups (descendants of prewar zaibatsu conglomerates). On August 20, 1999 Fuji, DKB, and IBJ announced a three way merger and a reorganization plan to create a financial group with specialized subsidiary organizations, commercial banking, investment banking, and trust banking. Sanwa and Tokai Banks, each having regional strength, announced their merger on March 14, 2000. These mergers can be regarded as a direct response of these banks to the banking crisis of 1997-98.

After several years of seemingly tranquil conditions, another financial crisis struck in 2002-03 when the bank regulator tightened standards in assessing and 
classifying NPLs and the use of deferred tax assets as part of capital, and introduced a requirement for reserves for NPLs. The effects of such regulatory tightening proved dire for many banks. In May 2003, for example, Resona Bank was determined to have failed and subsequently taken over by the government due to insufficient capital. In fact, many banks showed huge deficits following the regulatory tightening.

It was only after 2005 that the Japanese banks regained financial profitability and strength. Major financial groups in the Japanese banking sector posted positive net profits for the accounting years from 2005 to 2007 and they have completed repaying government injected funds that flowed into the predecessors of financial groups in 1998 and 1999. The capital adequacy ratio has improved far above 8\%, and the NPL ratio now lower than $5 \%$ by 2008 .

Traditionally, the government policy separated financial service industries into specialized segments and did not allow financial consolidation across segmentation. Commercial banking, trust banking, long-term credit banking, securities, and insurance had to be operated separately and independently. The Antimonopoly Law of 1949 prohibited financial holding companies as well as general holding companies for five decades then it was revised in 1997. The revised Antimonopoly Law and the Banking Law of 1981 opened the way for full financial integration across financial segments via financial holding companies (FHCs), a parent of different financial institutions. ${ }^{1}$ All major Japanese banks are now under these FHCs and they are listed on market and report consolidated financial statements. Due to consolidations sometimes across the segmentation boundary, most banks' balance sheets are not

1 Under the new Article 9 of the Antimonopoly law, the establishment and operation of a holding company is permitted. Along with the amendment of the Banking Law in 1998, Japanese banks could establish holding companies and become subsidiaries of them. Most holding companies in the banking sector then changed into financial holdings. 
directly comparable before and after respective mergers. Our analysis carefully examines the comparable balance sheets, as much as possible.

High on the list of primary motives for a merger of financial institutions, many cite reduction in costs and enhancement of revenues, taking advantage of scale economies. According to the Group of Ten (2001) report, the most important forces encouraging consolidation are improvement in information technology, financial deregulation, globalization of markets, and increased shareholder pressure for financial performance. That is, consolidations were part of strategic management. Improvement in competitiveness and policy implications were analyzed by several papers. Calomiris and Karceski (1998) and Calomiris (1999) were a survey of earlier study of bank consolidations and categorized the literature based on type of the research.

As Ito and Harada $(2005,2006)$ examined, market assessment and evaluations of Japanese banks went down sharply in the 1990s. Their stock prices fell more than the market average, and the so-called Japan premium emerged after 1997. The Japan premium was found to have responded most to news about bank failures and disclosed losses (see Peek and Rosengren (1998)). However even after their mergers, evaluations in the markets did not improve, and low evaluations prompted some to question whether mergers have made Japanese banks healthier, and whether their soundness has improved.

It was speculated in informed media that Japanese banks chose mergers in order to rescue weaker banks. Only a few academic papers existed to evaluate quantitatively the financial effect of mergers. Traditional methods of examining the effectiveness of mergers include comparing the pre- and post-merger ratios of 
operation costs, per-employee profits, and capital. Most traditional methods require long enough data points for quantitative analysis. Also those analyses would be backward-looking at the same time.

One popular method in the existing literature is to compare stock prices of merged banks. The stock prices reflect market expectations of future performances so comparing their prior to and following the merger may be a good way to make assessments. However, due to their mergers, most bank prices are not directly comparable before and after mergers. For example, the pre-merger stock price and post-merger stock price have different units. So items in financial statements changed due to mergers and unreported intra-group transactions making analyzing subsidiaries (financial institutions under the parent) difficult. Additionally, merger accounting employed in Japan differed from that used in other countries. The purchase method is standardized, but most mergers in Japan use the pooling-of-interests method. ${ }^{2}$

To overcome the difficulties mentioned above, we propose to use the concept of the distance to default (DD) as a method to evaluate the pre- and post-merger performances. The DD in the paper is a structural approach which is based on Merton (1974)'s model and Black and Scholes (1973) option pricing model. The method is forward-looking and overcome difficulties of non-comparability of stock prices due to restructuring associated with mergers.

Our main findings will be that mergers of Japanese banks did not make them

2 There are two methods for reporting for financial statement of mergers: the pooling-of-interest method and the purchase accounting method. Under the pooling-of-interest method, the balance sheets of a company in the merger are simply added together with the book values of their net assets without indicating which entity was the "purchaser" and which was the "purchased". When this method is used, it becomes difficult to tell who is buying whom or to determine how to evaluate the transactions. With the purchase method, one company is identified as the buyer. The buyer records the assets of the company being acquired on its books at the price it actually paid. 
financially healthier. This result confirms the suspicions that Japanese banks did not become healthy after their mergers. Adding two weak banks would not produce a strong bank.

The rest of the paper is organized as follows. Section 2 reviews the Japanese banking sector performance over the past 15 years. Section 3 describes the DD methodology and reviews the DD application to banks. We create two types of hypothetical banks, one is called as the Benchmark bank and the other one is called as a hypothetical bank in which balance sheets and stock prices prior to a merger is combined in section 4 . in order to compare the DD before and after the mergers. The empirical results are presented in the latter half of section 4 . Section 5 concludes the paper.

\section{The Japanese banking sector performance, 1990-2005}

This section reviews the history of bank failures and consolidations in Japan for the period between 1990 and 2005, as well as the literature on the performance of Japanese banks. Japanese stock prices and land prices tripled and quadrupled in the second half of the 1980s. The stock price index peaked on the last business day of 1989, and land prices peaked about one year later. They then plummeted from 1990 to 1992. No one knew at the time that the declining trend would continue until 2003.

The bursting of the bubble that caused stock price declines across-the-board and causing many bank loans non-performing made bank profit turn negative and eroded bank capital substantially. Actual realized losses and prospective losses that require reserves to be accumulated cause sharp decline in bank capital among all Japanese banks. According to the Basle capital adequacy standard, internationally-active banks have to maintain a capital ratio of $8 \%$ to the risk-adjusted 
asset. In November 1997, the Hokkaido Takushoku Bank (Takugin), one of the then twenty big banks, failed citing eroded capital and diminished liquidity. In the same month, one of the big four securities firms, Yamaichi Securities, also failed after the revelation of large previously unreported losses. Two other financial institutions failed in the same month. This raised the sense of crisis, and in March 1998, the government injected public funds to help raise capital adequacy ratios of major banks.

Despite the efforts to stabilize the financial system, two large banks-the Long-term Credit Bank (LTCB) and Nippon Credit Bank (NCB)-were found to be under-capitalized and were nationalized in 1998, as the aggressive action by FSA became possible by a newly introduced law. More public money had to spend to takeover, restructure, and sell to the new owner of these two banks. More public funds were injected as preferred stocks to supposedly sound banks in March 1999.

These developments, especially takeover of LTCB and NCB, sent an unmistakable signal to surviving banks that a lack of capital may result in sudden death, brought about by either the market or the regulator. Large banks attempted various ways to increase capital. Under such circumstances, a financially weak bank with less than sufficient capital can seek to merge with a stronger bank with a sufficient capital buffer. The merged bank may take advantage of scale economies in operation, cutting down operating costs. Expecting higher net earnings of the future, the stock market may favorably price the stock of a merged bank immediately after the merger (or so the bank hoped). However, Hirota and Tsutsui (1999), covering the data up to 1994, find interesting implications for economies of scale. They examine the risk-cost hypothesis of Japanese banks and find the estimates of scale elasticities become smaller as the bank becomes large. They show that Japanese large banks, before mergers, had already exploited the gain from the scale of economies. 
The difficulties among Japanese banks have been analyzed in many papers, but few papers are focusing on recent mega-mergers with formal empirical analysis. Ito and Sasaki (2002) analyzed how Japanese banks reacted to a falling capital ratio in the first half of the 1990s. They showed that the banks with a lower capital ratio tended to issue more subordinated debts to increase their capital ratio and made commercial loans less than in the past. One important footnote is that until 2002, the announced capital ratio did not show the true capital ratio. The discrepancy was due to optimistic classifications of NPLs. For example, insufficient reserves toward problem loans, use of subordinated debts, and counting tax deferred asset toward tier I capital made the Japanese banks' capital ratio higher than a true core capital ratio. In one instance, Long-term Credit Bank of Japan failed in September 1998, despite its strong capital ratio, above 11\%, in March 1998.

In the literature on difficulties of the Japanese banking sector in the 1990s, several papers are notable. Hoshi and Kashyap (2001) painted a bleak picture of the relationship between Japanese banks and corporations from the corporate governance point of view. Chapters in Cargill, Hutchison, and Ito $(1997,2000)$ give detailed descriptions of the earlier stages of Japanese banking failures. Peek and Posengren (1998) investigate the effect of Japanese bank failures in terms of the Japan premium. Hoshi and Ito (2004) review the evolution of the regulatory system in Japan from 1998 to 2004. Sakuragawa and Watanabe (2007) evaluated the Takenaka reform of 2002, which was usually credited for the revival of the Japanese banking sector after 2003.

We argued in Ito and Harada $(2005,2006)$ that Credit Default Swaps (CDS) premiums for Japanese banks can be a new criterion in addition to the Japan premium, the NPLs, and the capital adequacy ratio. Other papers analyzing Japanese banks with CDS are Ueno and Baba (2006) and Okada (2007). Ueno and Baba (2006) estimate 
the default intensity using CDS and find that the default intensities for the banks and the government substantially rose in the late 1990s. Okada (2007) uses an event study approach to study the reaction of the CDS market and finds that banks in general became less efficient after mergers. Ito and Harada $(2005,2006)$ find that interbank premiums do not reflect the soundness of Japanese banks and CDS is an alternative measure to see the market participants' view.

However, CDS is not traded for companies and institutions that are already in financially bad shape. Government affiliated companies and relatively small size companies are not traded in CDS market either. With the DD measure, we can evaluate those banks which are government affiliated and which are not traded in CDS market. The DD is employed as a measure of bank risk because the DD is a comprehensive measure of default risk (See Gropp and Moerman(2004), De Nicolo and Tieman (2006) and Gropp, Lo Duca and Vesala (2006)).

Bank failures and mergers and acquisition (M\&As) are relatively new phenomena in Japan. The first case of a bank failure that prompted assistance from the Deposit Insurance Cooperation of Japan was Toho Sogo Bank in 1991. The first listed bank failure was Hyogo Bank on August 30, 1995. Since then, many banks including some major banks failed, some of which were merged with healthier banks and some of which were temporarily nationalized. Harada and Ito (2008) created a list of these failed banks.

Among surviving banks, mergers were a popular step toward restructuring and capital strengthening. In the following years large banks opted for creating a holding company structure. As examined in Harada and Ito (2008), major banks went through complicated mergers and reorganizations in a short period of time. This requires whoever analyses the banks' balance sheets before and after the merger to compare the 
pre- and post-merger balance sheets very carefully so that assets and liabilities of pre-merger banks aggregate into a post-merger assets and liabilities.

Earlier studies of bank mergers in Japan such as Tachibanaki and Haneda (1999) typically relied on profitability and cost indicators pre and post the mergers. However, those analyses need information covering a long span of time and the evaluation of mergers is looking backwards. Hosono, Sakai, and Tsuru (2007) explored the causes and consequences of Japanese banking consolidation mainly what took place in the 1990s. They examine major banks, regional banks and shinkin banks. Regional banks are classified into first-tier regional banks and second-tier regional banks, which are not usually listed. Shinkin banks are also unlisted banks so they mainly use financial statement data. As we mentioned, the credibility of financial statements of merged banks are sometimes questioned. Further, financial statements data are not issued frequently and they have a significant time lag. In this paper, we overcome the shortcomings of earlier studies by using information derived from market prices (which are more accurate, frequent and timely than that derived from other sources). A method, the DD, is used in analyzing Japanese banks and evaluated bank performance comprehensively.

For nonfinancial corporations, the DD has become well known as a market-based measure for assessing the default or credit risk. It is only recent that the measure is also applied to financial institutions. It is mainly used by international organizations and monetary authorities to assess the financial stability and to monitor the risk of financial institutions For example, ECB (2005) treats the DD as an important forward-looking indicator that can provide early signs of financial fragility. In the case of cross-border contagion, the DD can be used as a comprehensive measure of default risk (Gropp, Lo-Duca and Vesala (2006), De 
Nicolo and Tieman (2006)). Chan-Lau and Sy (2006) introduce the concept of the distance to capital (DC) that accounts for pre-default regulatory actions such as prompt-corrective-actions framework. The distance to insolvency (DI) measures are introduced and applied by Danmarks National Bank (2004). The DI is the base from which these new measures were derived and it is applied for analyzizing various risks such as contagion risk (Duggar and Mitra (2007) and Chan-Lau, Mitra and Ong $(2007))^{3}$. The default barrier may be consistent with pre-default regulatory actions thresholds rather than book value of liabilities because intervention typically occurs at positive capital ratios. However, during the period in the analysis, regulatory and supervisory system was not consistent and complex. Therefore, our default barrier is book value of liabilities.

As mentioned above, mergers of major city banks took place in the early 2000s. These mergers were prompted, at least in part, by changes in the supervisory environment. In October 2002, the Financial Rehabilitation Program was released by Mr. Takenaka, then Minister in charge of the Financial Services Agency (FSA). The program urged major banks to apply strictly the existing accounting standard, which would increase non-performing loans and associated capital costs, and then to reduce the NPL ratio by a half in three years. A logical consequence was to attract new capital to make up the loss of existing capital, in order not to fall below the critical Basle capital adequacy ratio ( $8 \%$ for internationally-active banks). The FSA forced banks to disclose information in a conservative manner, and, if banks fall behind, the government was prepared to take over temporarily even a large bank. Some banks

3 Chan-Lau and Sy (2006) argued that the distance-to-capital (DC) measure may be more appropriate than the distance-to-capital (DD) measure, since the prompt corrective actions may be triggered by the supervisory authority before a bank becomes insolvent. They calculated the DC and DD for Resona and Ashikaga banks before their nationalization in 2003. 
needed to raise capital quickly, some other merged to become larger, presumably taking advantage of scale economies.

\section{Application of the DD to banks}

A critical question in evaluating bank mergers is whether a merged bank, in comparison with predecessor banks, will become a financially better bank, a worse bank, or just an average, compared to the predecessors. We propose to answer this question by examining the DD of the predecessor banks and that of the merged bank. ${ }^{4}$ It would become possible to examine whether a merger of unhealthy banks produces a healthy bank.

The DD is an application of credit risk assessment pioneered by Merton (1974) and Black and Scholes (1973) option pricing theory. ${ }^{5}$ The model defines a default when the book value of liabilities (the default point) of a company is below the market value of assets. The point where the book value of liabilities of a company is just equal to the market value of assets is called default point. The DD is the number of standard deviations away from the default point. The larger the $\mathrm{DD}$, the greater the distance of a company from the default point, less the risk or probability of default.

The option pricing theory determines the asset value and its volatility of a company from the observed stock price and stock volatility. Specifically, the level and the volatility of assets are calculated with the Black and Scholes (1973) model using

\footnotetext{
4 In this paper our method ignores possible default correlation of predecessor banks and calculating the joint default probabilities. As an example, when there are three predecessor banks, three DDs are calculated separately in order to examine how fragile the predecessors are individually and not to examine the likelihood that the three banks will default simultaneously.

5 See Crosbie and Bohn (2003) and Duffie et al (2007) for specific application of the theory.
} 
the value and volatility of stocks. Once the asset market value and its volatility are known, it is possible to calculate the probability that the asset value declines to the default point within a specified time. This probability is the default probability that corresponds one to one with the DD.

Here the DD rather than the default probability is used to examine a merger effect. ${ }^{6}$. Having the same level of the DD means that the two banks are at the same distance (in terms of standard deviation) from its default point respectively and have the same level of default risks. Since the DD is a market based measure of distress, it contains expectations of market participants and it is forward looking. Gropp, Vesala and Vulpes (2006) and Gropp amd Moerman (2004) argue that the DD may be a particularly suitable and all-encompassing measure of default risk for banks.

The DD is defined as follows:

$D D_{t}=\frac{\log \left(\frac{V_{t}}{L_{t}}\right)+\left(\mu_{A}-\frac{1}{2} \sigma_{A}^{2}\right) T}{\sigma_{A} \sqrt{T}}$

where $V_{t}$ is the market value of the bank's assets at time t, $L_{t}$ is the bank's liability at time t, $\mu_{A}$ is the mean growth rate of $V_{t}, \sigma_{A}$ is the standard deviation of $\mu_{A}, \mathrm{~T}$ is a time horizon, that is the time until default occurs which is set to one year. This assumption is common when particular information about the maturity structure of liabilities is not available. If $L_{t}$ does not change until $t+T$ (i.e. $L_{t}=L_{t+T}$ ), we can interpret the numerator of $D D_{t}$ as $E_{t}\left(\log V_{t+T}-\log L_{t+T}\right)$. This is because $V \mathrm{t}$ follows a geometric Brownian motion with mean $\mu_{\mathrm{A}}$ and standard deviation $\sigma_{\mathrm{A}}$,

6 Alternatively, the default probability could be used for a similar analysis. The DD and default probability, by definition, have negative relationship: when one becomes higher, the other becomes lower. However, the DD is more popular in the related literature 
and hence $\log V_{t+T}$ is distributed as logarithmic normal distribution and distributed as $N\left(\log V_{t}+\left(\mu_{A}-\frac{1}{2} \sigma_{A}^{2}\right) T, \sigma^{2} T\right) \cdot 7$

The DD is also expressed as follows:

$D D_{t}=\frac{E_{t} \log \left(V_{t+T}\right)-\log L_{t+T}}{\operatorname{std}\left(\log \left(V_{t+T}\right)\right)}$

where $\operatorname{std}()$ is standard deviation. Hence, $D D_{t}$ and the default probabilities of the structural model correspond to each other one for one. These assumptions and modeling tell us that a negative DD implies $E_{t}\left(\log V_{t+T}\right)<\log L_{t+T}$. As the market value of the assets follows logarithmic normal distribution, the negative DD means that a probability of default $\left(V_{t+T}<L_{t+T}\right)$ at time $\mathrm{t}+\mathrm{T}$ is greater than 0.5 .

$D D_{t}$ is calculated using the data as follows; $L_{t}$ is from the bank's balance sheet and set $\mathrm{T}$ equal to one year. In order to estimate $V_{t}, \mu_{A}$, and $\sigma_{A}$, we use the Black and Scholes option price model.

$$
\begin{aligned}
& W_{t}=V_{t} \Phi\left(d_{1}\right)-L_{t} e^{-r T} \Phi\left(d_{2}\right) \\
& \sigma_{A}=\operatorname{std}\left(\ln \left(V_{t}\right)-\ln \left(V_{t-1}\right)\right)
\end{aligned}
$$

where

$d_{1}=\frac{\log \left(\frac{V_{t}}{L_{t}}\right)+\left(r+\frac{1}{2} \sigma_{A}^{2}\right) T}{\sigma_{A} \sqrt{T}}$

$7 E_{t}\left(\log V_{t+T}-\log L_{t+T}\right)$ is derived as follows;

$$
\begin{aligned}
E_{t}\left(\log V_{t+T}-\log L_{t+T}\right) & =E_{t}\left(\log V_{t+T}-\log L_{t}\right) \\
& =\log V_{t}+\left(\mu_{A}-\frac{1}{2} \sigma_{A}^{2}\right) T-\log L_{t} \\
& =\log \left(\frac{V_{t}}{L_{t}}\right)+\left(\mu_{A}-\frac{1}{2} \sigma_{A}^{2}\right) T
\end{aligned}
$$


$d_{2}=d_{1}-\sigma_{A} \sqrt{T}$

Here, $r$ is the risk-free rate, $W_{t}$ is the market value of equity at time $\mathrm{t}$ (stock prices times number of shares outstanding), $\Phi$ is the standard normal cumulative distribution function. In order to estimate $V_{t}, \mu_{A}$, and $\sigma_{A}$, we use the following steps with the gradient method. First, we set the initial guess for $V_{t}^{0}, V_{t-1}{ }^{0}, V_{t-T+1}{ }^{0}$ (previous year's data), then calculate $\sigma^{0}{ }_{A}$, using equation (4). We next calculate $V_{t}^{1}, V_{t-1}{ }^{1}, V_{t-T+1}{ }^{1}$ with $\sigma^{0}{ }_{A}$. As the next step, we calculate $\sigma^{1}$, using equation (4) and estimate $V_{t}{ }^{2}, V_{t-1}{ }^{2}, \ldots, V_{t-T+1}{ }^{2}$ using $\sigma^{1}{ }_{A}$. We repeat these steps until the values converge.

In order to compute the DD of a bank, the face value of near-term and long-term debts (financial statements) and market prices of the bank's stock are needed. The banking sector, however, has a balance-sheet structure that is quite different from non-financial companies. A careful consideration was given to classify what can be short-term debts and long-term debts of banks (see Appendix table 1). Items are in principle selected in terms of their maturity. Nevertheless the maturity may not be really economically relevant. For example, even the term deposits (of maturity more than a year) can be withdrawn if depositors forego part of accrued interest, so it could become short-term debt in the case of a bank run. ${ }^{8}$ We have to make several judgments in defining short-term debts by examining each item.

As mentioned above, the number of the DD is the distance from the default point in terms of standard deviation of asset value fluctuation. For example, a DD of 2.0 means that the default within a year is a two-standard deviation event presuming

\footnotetext{
8 Interim (a minor of the semi-annual) financial statements of Japanese companies do not contain detailed sub-items of time deposits and it is impossible to treat total debt minus time deposits as short-term debt.
} 
the fluctuation of mark-to-market asset values follows the recent historical value, using the current mark-to-market asset value as a starting point. Even if the DD becomes zero, it does not mean that the bank fails at that point of time. The zero DD means that if short-term debts (liabilities with maturity less than a year) are not rolled over and extra profits are not earned, then the bank or the company would exhaust assets within a year. The DD being 0.0 or even negative means that the bank will be highly likely to fail under no-rollover assumption. However, if the short-term debts are rolled over, then it survives on the cash flow basis, although it may become technically insolvent. While if short-term debts are called (time deposits withdrawn in a bank run), then it may fail at once. If and when the DD of a bank approaches zero, it implies the bank is in an extremely vulnerable position. In the event of a bank run, sudden death may be certain.

There have been two accounting methods of merger in Japan. The pooling-of-interest method which unites the book value of assets and the book value of liabilities of merging banks. In contrast, the market value of assets is used for the merged entity. The latter method is preferable for the analysis of the DD. However, the

former method was the preferred one among the Japanese bank mergers. That makes it difficult to measure the market value of their mergers. Our analysis of the DD tries to overcome the discontinuity in the data and takes into consideration market evaluation. We provide a picture of how banks and financial holding companies performed in terms of financial health, measured by the DD, prior to and following mergers.

\section{The DD of Japanese banks}

\subsection{Data}

Annual balance sheets, income statements, daily stock prices and the number of issued 
stocks for each bank are obtained from the Nikkei Financial Quest database. Our data covers the period of fiscal year 1985 to August 2005. Most mergers took place around 2000 , so that the after-merger period is limited, although our data can describe how the DD of major banks behaved over two decades. ${ }^{9}$

In order to calculate the $\mathrm{DD}$, data on the risk free rate, market capitalization, total assets (book value), stock holder's equity (book value) and short-term liability are needed. For the risk free rate, the 3-month Saiken Gensaki rate (or the 3-month bond repurchase rate) is used for the period of April 1, 1985 to May 31, 1992, and then the 3-month Financial Bill (FB) rate is used for the period of June 1, 1992 to August 12,2005 . This is because the government short-term paper (FB) yield is only available from1992. During the 1980s, bond repurchase was on some days not priced so that adjacent values of the risk free rate are used when some values are missing. Market capitalization data is defined by daily stock prices (closing price) times the number of issued stocks. When the closing stock price is not available, we applied the same method; that is, if one day is missing the previous day's data was copied. Several days missing; a gradual adjustment using two edge's data, like linear interpolation for normal approximation of binomial distributions.

Regarding accounting data, we examined organizational structure under holding companies and a number of subsidiaries included in consolidated financial statements. ${ }^{10}$ Unconsolidated financial statements of a bank represent the banks' healthiness however in most cases the data is not available because banks are de-listed

\footnotetext{
9 In our sample, Mitsubishi Tokyo Financial Group (MTFG) and UFJ Holdings are two separate bank holding companies. Bank of Tokyo-Mitsubishi and UFJ Bank merged on January 1, 2006 to form The Bank of Tokyo-Mitsubishi UFJ, Ltd. Our data period does not cover this merger.

10 Changes in organizational structure are thoroughly examined in Harada and Ito (2008).
} 
when holding companies are listed instead. ${ }^{11}$ Most banks do not necessarily report their statements unless they issue bonds.

Consolidated financial statements and income statements are used as an alternative as parent companies' unconsolidated statements do not contain relevant information. For Mizuho Bank, Mizuho Corp. Bank, Bank of Tokyo Mitsubishi, UFJ Bank, consolidated statements, but for Sumitomo Mitsui Bank, and unconsolidated statements are available and used. ${ }^{12}$ For the details of short-term liability data, see Appendix Table1.

In our study of the Japanese banking sector between 1985 and 2005, in order to separate individual bank merger effects from macro business conditions, we created a benchmark bank that are free from any merger event during the sample period. Since all major (city) banks went through reorganization, creating financial holding companies (FHCs), they would not be appropriate for a continuous benchmark.. For benchmark, a group of five largest regional banks, namely, Chiba Bank, Yokohama Bank, Shizuoka Bank, Hiroshima Bank and Fukuoka Bank, is selected, because they were regarded as sound, and they did not experience any merger. ${ }^{13}$ Unconsolidated

11 The difference between Consolidated and Unconsolidated usually is due to including or excluding some smaller financial subsidiaries and overseas incorporated subsidiaries. How to match balance sheets pre and post is complicated sometimes (especially for Mizuho). At the time of merger, some assets (real estate, and good-will values) might be reevaluated, so that they may not match. Good-will values are capitalized to boost the capital ratio in some merger cases. See Harada and Ito (2008) for detail.

12 Interim (semi-annual) figures are not available until 2001 September so we use full year results from 1985 to 2001. Available items of financial statements in interim figures are different. As an example, sub-items of total deposits are not available in interim figures.

13 We know treatments of large regional banks are different from those of city banks. As an example, government capital infusions and pressure to reduce NPLs are not the same. However, the regional banks are used for comparison.

As the DD is the measure used in the paper, the same measure is adopted for the benchmark for comparing merged banks and non-merged banks. That means, we did not employ another 
financial statements for each bank are used from March 1985 to March 2005. Daily stock prices and the number of issued stocks of these banks are used for the benchmark's market capitalization.

Obtaining the DD of the benchmark bank is straightforward. The DD for each regional bank is calculated as before, and then five DDs in the benchmark group are averaged. News which affects the banking sector as a whole is reflected in the benchmark as well as merged banks. So by comparing with the benchmark DD, the macro economic news can be controlled.

Our first question is whether a merger is neutral in financial health of banks. If a merged bank is just the sum of individual banks, then the merger considered to be neutral in terms of financial health. That is, "DD (bank A+ bank B+ bank C) pre-merger $=$ DD (new bank) post-merger" is a neutral case, "DD pre-merger $>$ DD post-merger" means a value-losing merger, and "DD pre-merger $<$ DD post-merger" means a value-creating merger taking advantage of, for example, scale economy.

A "hypothetical bank" in each merger is a counterfactual bank that is calculated by aggregating pre-merged banks' balance sheets and stock prices during the pre-merged period. The hypothetical, named "DD pre-[bank name]" (that is, the DD prior to Mizuho FG, the DD pre-MTFG, the DD pre-UFJ Holdings, and the DD pre-SMFG, respectively), is created using combined data of the predecessor banks. If the level of the DD of merged banks did not significantly change from the hypothetical bank pre-merger, then we regard the merger as not adding any value to financial strength. If the DD becomes lower post-merger, then the merger was counterproductive, in that the merger made the bank weaker.

methodology such as extracting idiosyncratic factor from separating beta of CAPM for these regional banks. 


\subsection{The pre and post merger DD}

In this subsection, the level of the pre and post merger DDs are examined using figures.

The DDs of a hypothetical bank and the merged bank are shown in each graph from 1985 to 2005 . In figures focusing after 2000 , the DD of the benchmark bank, the DDs of pre-merger banks are added to compare movements in the level.

\subsubsection{Mizuho Financial Group ${ }^{14}$}

Basic financial information of banks in the Mizuho Financial Group (Mizuho FG), the time period of their stocks being listed in the Tokyo Stock Exchange, and their market capitalization are shown in Appendix Table $2 .{ }^{15}$ Figure 1-1 is the DD pre-Mizuho FG was formed and the DD of Mizuho FG. Figure 1-2 is the DDs of each predecessor, the benchmark and the FG of recent years after 2000. The first one-year data is needed in the process of calculating the DD, so there are some discontinuities in the DD. Our interest is how the DD changed over the whole

14 DKB and Fuji are two independent banks until September 21, 2000. As such, unconsolidated financial statements are used until that date. From September 28, 2000 to August 12, 2005 Mizuho Holdings (Mizuho FG) is a listed company. Regarding financial statements, combined financial statements of DKB and Fuji are used until March 2003 because the listed company, Mizuho Holdings, is just an 'umbrella'. From March 2003 consolidated financial statements of Mizuho FG are available.

15. Note about stock price data of Mizuho; the before and after-merger price and the post-merger price have different units. They changed the unit. Before the merger, the unit of trade was 1,000 shares and after the merger, the unit of trade is 1 share. We have information on the number of shares outstanding. We know that the capitalization (price multiplied by shares) did not change. Difference in units is considered, however the following fact is not adjusted. After the merger, banks formed a holding company structure. The listed shares are for the holding company, and the holding company owns 100 percent of each bank as well as other financial institutions. Individual cases are different in how the merger was handled. Mizuho reorganized three banks (DKB, IBJ, Fuji) into two functional banks (Mizuho and Mizuho Corporate) and later they became the subsidiaries of the umbrella holding company, Mizuho Holdings. 
sample period, especially after 2000 .

We have six lines in figure1-2. DKB, Fuji Bank and IBJ were listed until September 21, 2000. Then these three banks were delisted and Mizuho Holdings, (later Mizuho FG), from March 12, 2003 was listed. The level of the DD of Mizuho Holdings after the merger did not significantly change from the DD pre-Mizuho FG, which was represented as the Mizuho Predecessor, in Figures 1-2.

In the 1980s, the DD of pre-Mizuho FG was above 2, ranging from 2 to 7. When the stock market bubble burst in the early 1990s, the DD fell toward zero until 1993. The DD remained positive but low from 1993 to $1997 . \quad$ From 1997 to spring of 1999, during the financial crisis period, the DD approached zero again, and then became negative. When the news of the merger was announced on August 20, 1999, the DD was deep in the negative territory and the DD suddenly became higher upon the merger news. ${ }^{16}$ Clearly, the merger news was welcomed by investors. Positive DD, however, did not last more than a year and again it became negative before the actual merger day. After the merger in Figure 1-2, the level of the DD did not improve and was negative until September 2003. ${ }^{17}$ On January 8, 2003, the Mizuho group created the Mizuho Financial Group (FG) and Mizuho Holdings became a subsidiary of the Mizuho FG, and banks and securities firm became subsidiaries of

16 The negative value comes together with negative asset growth. In theory, the DD should not be negative. It is possible to build a restriction in the program and truncate the DD at zero, however, we choose to leave it as it shows as the result is the same. Negative value could bring us caution and information.

17 Risks associated with leverage for a bank differs from that for a non-financial firm, given the different business model. This difference suggests that the higher leverage of a bank relative to a non-financial firm may lead to an overstatement of the measured risk of default relative to a non-financial firm. With this regard, we recalculated DD values however the results did not change much. The DDs of post-merger period of most merged banks were negative. 
Mizuho Holdings. Then, Mizuho Holdings was restructured into a subsidiary in parallel with other financial institutions on March 12, 2003. During the period of restructuring, the DD remained negative. Our analysis of the DD of the Mizuho group reveals that their mergers did not produce a healthy bank out of three weak banks, despite a brief period of enthusiasm after the merger news announcement.

\subsubsection{Mitsubishi Tokyo Financial Group}

Appendix Table 3 shows banks that became parts of the Mitsubishi Tokyo Financial Group (MTFG), with information of their listed period on the Tokyo Stock Exchange and market capitalization., Two merger events occurred during our sample period; one is Mitsubishi Tokyo Bank which is created by the merger of Mitsubishi bank and Tokyo bank on April 1, 1996 and the other one is the launch of MTFG on April 1, 2001. Figure 2-1 shows the DDs of Mitsubishi and Tokyo from 1986 to 1996. The DD of the former merger is measured in Figure 2-2 which covers the period 1995 to 1996. The hypothetical bank (BTM Predecessors in the figure) is a combined balance sheets of the Mitsubishi Bank and Bank of Tokyo. Figure 2-3 focus on the period after 2000 and show the DDs of three banks (the DD of BTM, the DD of MTFG and the Benchmark DD).

The level of the DD of Bank of Tokyo Mitsubishi in Figure 2-1 rose from negative to positive but they were low levels in the latter half of the 1990s and improve after their launch in 2001. Before the Bank of Tokyo Mitsubishi was established, the DD increased towards the merger in 1996. Around the merger time, the DD approached 6, a relatively high value. Movements in the DD in general show similar patterns with other banks in the 1990s, however, one remarkable feature for MTFG is that the DD turned positive when merger news was announced (March 28, 
1995) and increased towards the day of the merger. From Figure 2-3, one feature

of the MTFG is obvious. The DD of MTFG did not become negative after the merger or reorganization. This contrasts to other bank groups in our sample. The initial enthusiasm after the merger announcement was followed up by a firm belief of investors that the merger would be a successful one. The relatively high level of the DD shows that MTFG was regarded as a sound bank. In the following years, however, the level of the DD of MTFG stayed stable, in contrast to other banks that experienced significant improvements.

\subsubsection{UF J Holdings}

UFJ Bank was formed by the merger of Sanwa Bank and Tokai Bank on April 2, 2001 and UFJ Holdings was established on the same day (see Appendix Table4). Figure 3-1 and Figure 3-2 are the DD of banks belonging to UFJ Holdings.

The merger was announced about one year earlier on June 15, 2000. However, the level of the DD did not change noticeably after the announcement. When UFJ Holdings was listed, the DD became and remained negative until mid-2003. It did not move into a positive territory until MTFG announced the forthcoming merger with UFJ Holdings on August 13, 2004.

After 2000, movements in the DD are similar with that of Mizuho FG. In Figure 3-2, there are two spikes, one is around the spring of 2004 and the other is during the summer of 2005. These spikes are related to the news of merger with the MTFG.

On May 21, 2004, UFJ Holdings announced it was selling UFJ Trust Bank to Sumitomo Trust Bank for 300 billion yen. However, on August 13, 2004, MTFG and UFJ Holdings announced that the holding company as a whole would merge 
with MTFG. The Mitsubishi UFJ Financial Group would be formed by the end of September 2005. (The new group name, Mitsubishi UFJ Financial Group, was announced February 18, 2005.) Although this news had a negative impact on MTFG because 0.62 MTFG share was the exchange unit for 1 UFJ share, it had a positive impact on the UFJ side. The market view, shown in DD movements, suggests that the merger was in favor for weak UFJ with low DD at the expense of strong MTFG with high DD.

\subsubsection{Sumitomo Mitsui Financial Group}

For the case of Sumitomo Mitsui Financial Group (SMFG), Appendix Table 5 explains how the two banks are consolidated into SMFG. Figure 4-1 shows the level of the DD before SMFG was formed. Figure 4-2 is the DDs of the predecessor, the benchmark and the FG after 2000.

Sumitomo Mitsui Banking Corp. (SMBC) was established by the merger of Sumitomo Bank and Sakura Bank on April 1, 2001 (The news was announced on October 14, 1999). Therefore the DD of the hypothetical bank, the pre-SMFG, the DD which are composed of Sumitomo Bank and Sakura Bank, covers the period from 1985 to March 2001. ${ }^{18}$ Later, on December 2, 2002, SMFG was formed and SMBC was absorbed by the Financial Group as one of its $100 \%$ subsidiary banks. SMBC which is under the SMFG merged with one of its subsidiary banks, Wakashio Bank, on March 17, 2003 (The news was announced on December 25, 2002). The

18 Sakura Bank was established in April 1990 by the merger of Mitsui Bank and Taiyo Kobe Bank. This merger case is not counted as one event in SMBC because the merger was guided by the authorities. 
complexity of the last merger makes the analysis more difficult in this case. ${ }^{19}$

The level of the DD suddenly became negative in December 2002 and this period is consistent with the announcement of its merger with Wakashio bank. The DD of SMBC dropped to zero and became negative when SMFG was listed in 2003.

\subsubsection{Summary and Interpretation}

By examining the four merger cases, a common pattern of DD movements among Mizuho FG, UFJ Holdings and SMFG is as follows: Their DDs before the merger was either in the negative territory or near zero, and after the merger, stayed near zero for about one to two years. MTFG was an exceptional case because its DD did not turn negative after the merger.

Three mergers out of four were regarded by the market as if they were nearly insolvent financial groups around the merger period. After their mergers, their financial health did not improve, at least immediately, according to the DD. The market participants were skeptical whether bank mergers would produce synergy and scale economies more than just the addition of the two (or three) banks' balance sheets.

If mergers did not produce the additional value, what could be a motivation of a merger? One possibility was that banks merged to become larger knowing, rightly or wrongly, that there existed a too-big-to-fail policy. The market was not impressed by this. Spiegel and Yamori (2004) states that the set of banks treated as too-big-to-fail were progressively narrowed as the financial situation deteriorated

19 Wakashio bank was established in June 1996 and started operation in September 1996. In March 2003 SMBC merged with Wakashio Bank but the merged bank's name became Sumitomo Mitsui Banking Corporation. In the merger, unrealized equity losses of SMBC were eliminated. See Harada and Ito (2008) for detail. 
and the funds of the Deposit Insurance Corporation were depleted. Earlier studies such as Brewer et al. (2003) find evidence in favor of some "too-big-to-fail" protection for large banks but the regulatory advantage of large Japanese banks no longer existed at that time. That is, our results with the DD are consistent with the findings in Spiegel and Yamori (2004). After the failures of two long-term credit banks, Long-Term Credit Bank of Japan and Nippon Credit Bank, in 1998, the market considered that weak banks might fail (and eventually taken over by the government) regardless of the asset size.

Turning to the period from 2003 to 2005, the DD movements of the three financial groups, Mizuho FG, UFJ Holdings and SMFG, are very similar. Their DDs improved dramatically after 2003. Behind the improvement is the fact that the amount of NPLs, which peaked in March 2002, continued to decline steeply until March 2005. "The Anti-Deflation Package" and "The Financial Revitalization Program" in October 2002 were considered as the impetus for resolving the NPLs. ${ }^{20}$ Stock prices of those merged banks substantially improved as well. All mega banks had experienced a turnaround. The results might suggest that it takes for merged banks a long time to bear fruits because cost savings by reorganization or system integration, avoiding conflicts with workers and customers, could proceed only gradually in Japan.

\subsection{T-test on the difference of the DD}

In this subsection, we formally test the level of the pre- and post-merger DDs. Two

\footnotetext{
20 Another turning point was the nationalization of the Resona Bank in May 2003. It was nationalized and capital was injected, but the existing shareholders' value was not scrapped, on the assumption that the capital had positive net capital, although the capital ratio was below a minimum standard $4 \%$.
} 
types of event windows, 250 business days and 500 business days, are examined for the changes in the level of the $\mathrm{DD}$, and a paired t-test is conducted on the differences between our bank of interest and the benchmark bank. ${ }^{21}$ This type of t-test is used to compare means on the same subject in differing circumstances which are a before and after comparison in the paper. The 250 day event window captures approximately one year pre- and post-merger. The 500 day event reveals the rather long term effects of mergers as they progress over two years after merger and display the effects.

We compare two paired groups which show the differences between the DD of a hypothetical bank and a merged bank, in order to control for news effects which affect the banking sector. The hypothesis is that the relative standing of pre- and post-merger banks are different. Given two paired sets $X_{i}$ and $Y_{i}$ of n observations, the paired t-test determines if they differ from each other in a significant way.

$$
\begin{aligned}
& \hat{X}_{i}=\left(X_{i}-\bar{X}\right) \\
& \hat{Y}_{i}=\left(Y_{i}-\bar{Y}\right) \\
& t=(\bar{X}-\bar{Y}) \sqrt{\frac{n(n-1)}{\sum_{i=1}^{n}\left(\hat{X}_{i}-\hat{Y}_{i}\right)^{2}}}
\end{aligned}
$$

where $\hat{X}_{i}$ displays pre-merger of the DD, $\hat{Y}_{i}$ shows data post-merger difference.

\subsubsection{Mizuho Financial Group}

The average DD of Mizuho FG is smaller than pre- and even post-merger compared with the benchmark DD in Table 1. It is 0.517 pre- and -0.743 post-merger for 500 day window, -0.030 pre- and -0.740 post-merger for 250 day window. Narrowing the

21 Under the paired t-test, it is assumed that the data come from the same subject and does not assume that the variance of populations is equal. 
event window, the DD of Mizuho FG are both negative (-0.030 and -0.740$)$. The average DD the merger period is below zero and the soundness of these banks does not appeared to have changed even after forming a new financial group.

The paired t-test is for the pre- and post-merger difference and specifically, the difference between the DD of Mizuho FG and that of the benchmark is calculated for both pre- and post-merger differences. For the pre-merger period, the difference between the DD of Mizuho Predecessors and that of the benchmark is conducted. The null hypothesis of no difference is rejected at the $1 \%$ significance level (They are -31.66 and -44.36 in Table 5). As the difference is negative, it implies that Mizuho FG was considered a weaker bank than large regional banks.

\subsubsection{Mitsubishi Tokyo Financial Group}

In Table 2, event 1 is the merger of Mitsubishi Bank and Tokyo Bank in 1996 and event 2 is the merger of MTFG. Our results were basically the same in both events.

The average DDs of Mitsubishi Bank and MTFG are mostly larger than that of the pre- and post-merger DDs of the benchmark bank. This is an outstanding difference because no merger event improved the level of the DD except the case of this group. For event 2, the average DD for benchmark is 1.972 pre-merger and 1.721 post-merger and those of MTFG are 0.637 and 1.659 in 500 day window, and 0.192 and 1.642 in 250 day window. It shows that launching MTFG was a positively evaluated and it lessened the default probability of the bank.

The paired t-test for MTFG is also significant at $1 \%$ level and the difference is statistically significant pre- and post-merger periods. However, the magnitude of difference itself is smaller when compared with other banks. They are for example 
-25.6 and -9.1 for the establishment of MTFG (event 2) in Table5.

\subsubsection{UF J Holdings}

The average DD of UFJ Holdings in Table 3 is quite similar to the case of Mizuho FG. The level of the DD became smaller pre- and post-the merger compared with the benchmark bank. It is 0.384 before the merger and -0.857 after the merger for the 500 day window; and 0.454 before the merger and -1.868 after the merger in the 250 day window. The DD for the benchmark bank was stable during the period but sharply lowered after the launch of UFJ Holdings. The average DD was below zero after the event. These results are consistent with that the core bank of UFJ Holdings, Sanwa bank had a huge amount of NPLs and their asset quality was poor compared with other banks. Our result implies that the default risk of UFJ Holdings did not improve by the merger.

The results of paired t-test are -70.44 and -24.29 for UFJ Holdings in Table 5. Again, the null hypothesis of no difference is rejected at the $1 \%$ significance level. As the difference was negative, UFJ Holdings was also considered a weaker bank than major regional banks.

\subsubsection{Sumitomo Mitsui Financial Group}

The average DD of SMFG is smaller than that of benchmark bank after the merger.

(Table 4). The result is similar with those of Mizuho FG and UFJ Holdings. That is, the average DD became smaller in the latter half of the event window and was smaller than that of the benchmark bank.

The paired t-test for SMFG is significant at 1\% level. Again the result is similar to Mizuho FG and UFJ Holdings. The pre and post-merger performances of 
these banks were different (Table 5). All in all, our results support the view that mergers did not create healthier banks for these banks, or, at least, so perceived by the market. The difference of the DD for pre- and post-merger periods was significantly different for all banks and that implies the performance of the DD of merged banks were not the same with original predecessors.

\section{Conclusions}

The paper examines whether or not bank mergers in the late 1990s and 2000s enhanced their financial soundness and helped banks escape from failure. Banks are considered to be fragile and heading toward failure, when their capital base is eroded, when a large portion of their loan is nonperforming, and/or when potential losses from other sources are apparent. One way to enhance capital is to raise profitability, and one way to enhance profitability is to merge with another bank and take advantage of scale economies, by eliminating duplicating costs and making synergy to work. Between 1997 and 2003, many banks attempted to enhance their capital base via mergers. Some mergers were genuinely attempting to achieve scale economies, while others seemed to put priority to get bigger. Yet, a few cases seemed to take advantage of accounting tricks involving realizing going-concern values on books.

Our results show that financial soundness of a merged bank depended heavily on that of the pre-merged banks. Mergers do not automatically guarantee improvement of banks' financial health, as the level of the DD did not rise after the merger in three out of four cases in our sample. A merger of sound banks produces a sound merged bank, but adding two weak banks did not produce a strong bank. 
Mergers did not help lessen the probability of failure (with a notable exception of MTFG). On of the reasons for this result is that Japanese banks chose "equal merger", as opposed to takeovers, and that limited a scope of serious restructuring after mergers. Also the merger accounting method used was based on a method that is not a widely accepted abroad. These facts would explain the behavior of the DD.

In addition, not only did the merger produce similar DDs of the pre-merged banks, but a merged bank often experienced the negative DD right after the merger. These findings are consistent with the view that mergers were not motivated by a desire and determination to restore sound banking, at least so perceived by the market. 


\section{Reference}

Black, Fisher and Myron Scholes (1973), "The Pricing of Options and Corporate Liabilities," Journal of Political Economy 81(3), 637-654.

Brewer, Elijah III, Hesna Gray, William C. Hunter, and George C. Kaufman (2003), "Does the Stock Market Price Bank Risk? Evidence from Bank Failures," Journal of Money, Credit ansd Banking 35, 507-543.

Calomiris,Charles.W. and Jason Karceski (1998), "Is the Bank Merger Wave of the 1990s Efficient? Lessons from Nine Case Studies," in Kaplan, Steven.N. (edt.) Mergers and Productivity, University of Chicago Press, 99-161.

Calomiris, Charles.W. (1999), "Gauging the Efficiency of Bank Consolidation during a Merger Wave," Journal of Banking and Finance 23, 615-621.

Cargill, Thomas F., Michael M. Hutchison, and Takatoshi Ito (1997), The Political Economy of Japanese Monetary Policy, MIT Press.

Cargill, Thomas F., Michael M. Hutchison, and Takatoshi Ito (2000), Financial policy and Central Banking in Japan, MIT Press

Chan-Lau, Jorge A., Srobona Mitra, and Li Lian Ong (2007), "Contagion Risk in the International Banking System and Implications for London as a Global Financial Center," IMF Working Paper 07/74. 
Chan-Lau, Jorge A. and Amadou N.R. Sy (2006), "Distance-to-Default in Banking: A Bridge Too Far?," IMF Working Paper 06/215.

Crosbie, Peter, and Jeff Bohn (2003), "Modeling Default Risk,” Moody’s KMV White Paper, (San Francisco: Moody’s Investor Service) December 18.

Duffie, Darrell, Leandro Saita and Ke Wang (2007), Multi-Period Corporate Default Prediction with Stochastic Covariates, Journal of Financial Economics 83(3), 635 - 666.

Danmarks National Bank (2004), Financial Stability Report (Copenhagen). Available via the internet at http://www.nationalbanken.dk

De Nicolo, Gianni and Alexander Tieman (2006), "Economic Integration and Financial Stability: A European Perspective”, IMF Working Paper 05/296.

Duggar, Elena and Srobona Mitra (2007) "External Linkages and Contagion Risk in Irish Banks," IMF Working Paper 07/44.

European Central Bank (2005), Financial Stability Review, June (Frankfurt).

Gropp, Reint and Gerard Moerman (2004), Measurement of Contagion in banks' equity prices, Journal of International Money and Finance 23, p405-459.

Gropp, Reint, Marco Lo Duca and Jukka Vesala (2006), "Bank Contagion in Europe", European Central Bank Working Paper Series 662. 
Gropp, Reint, Jukka Vesala, Giuseppe Vulpes, (2006) "Equity and Bond Market Signals as Leading Indicators of Bank Fragility," Journal of Money, Credit and Banking, 38(2), p.399-428

Group of Ten (2001), "Consolidation in the Financial Sector," (available at BIS homepage; http://www.bis.org/publ/gten05.pdf)

Harada, Kimie and Takatoshi Ito (2008), "Mega-Mergers in Japan: Economic Reasons and Performances," mimeograph.

Hirota, Shinichi and Yoshiro Tsutsui (1999), "Do banks diversify portfolio risk? A test of the risk-cost hypothesis," Japan and the World Economy 11, 29-39.

Hoshi, Takeo and Anil Kashyap, (2001), Corporate Financing and Governance in Japan: The Road to the Future, MIT Press, Cambridge, Mass.

Hoshi, Takeo and Takatoshi Ito (2004), "Financial regulation in Japan: a sixth year review of the Financial Services Agency", Journal of Financial Stability 1, 229-243.

Hosono, Kaoru, Koji Sakai, and Kotaro Tsuru (2007), “Consolidation of Banks in Japan: Causes and Consequences," presented at the NBER $18^{\text {th }}$ EASE conference, June..

Ito, Takatoshi and Kimie Harada (2005), “Japan Premium and Stock Prices: Two Mirrors of Japanese Banking Crises,” International Journal of Finance \& Economics 10, 195-211. 
Ito, Takatoshi and Kimie Harada (2006), "Bank fragility in Japan 1995-2003," in Hutchison, M.M. and Westermann, F. (eds), Japan's Great Stagnation Financial and Monetary Policy Lessons for Advanced Economies, MIT Press

Ito, Takatoshi and Yuri N. Sasaki (2002), "Impacts of the Basle Capital Standard on Japanese Banks' Behavior," Journal of the Japanese and International Economies 16, 372-397.

Merton, Robert C. (1974), "On the Pricing of Corporate Debt: the Risk Structure of Interest Rates," Journal of Finance 29, p.449-470.

Okada, Tae (2007), "Consequences of Bank Mergers [Ginko gappei no kouka, in Japanese], mimeograph.

Peek, Joe and Eric Rosengren (1998), "Determinants of the Japan Premium: Actions Speak Louder than Works,” Journal of International Economics, 53(2), p.283-305.

Sakuragawa, Masaya, and Yoshitsugu Watanabe (2007), "Did the Japanese Stock Market appropriately Price the Takenaka financial reform ?," presented at the NBER $18^{\text {th }}$ EASE conference.

Spiegel, Mark, and Nobuyoshi Yamori (2004), "The Evolution of Bank Resolution Policies in Japan: Evidence from Market Equity Values," Journal of Financial Research, _ , , , $115-132$. 
Tachibanaki, Toshiaki and Akihiko Haneda (1999), "The Effects of Mergers in City Banks," Financial Review, Ministry of Finance Japan, 52 (in Japanese), 139-176.

Ueno, Yoichi and Naohiko Baba (2006), "Default Intensity and Expected Recovery of Japanese Banks and "Government": New Evidence from the CDS Market," Bank of Japan Working Paper Series No.06-E-04. 
Figure 1-1 Mizuho FG DD from 1985 to 2005

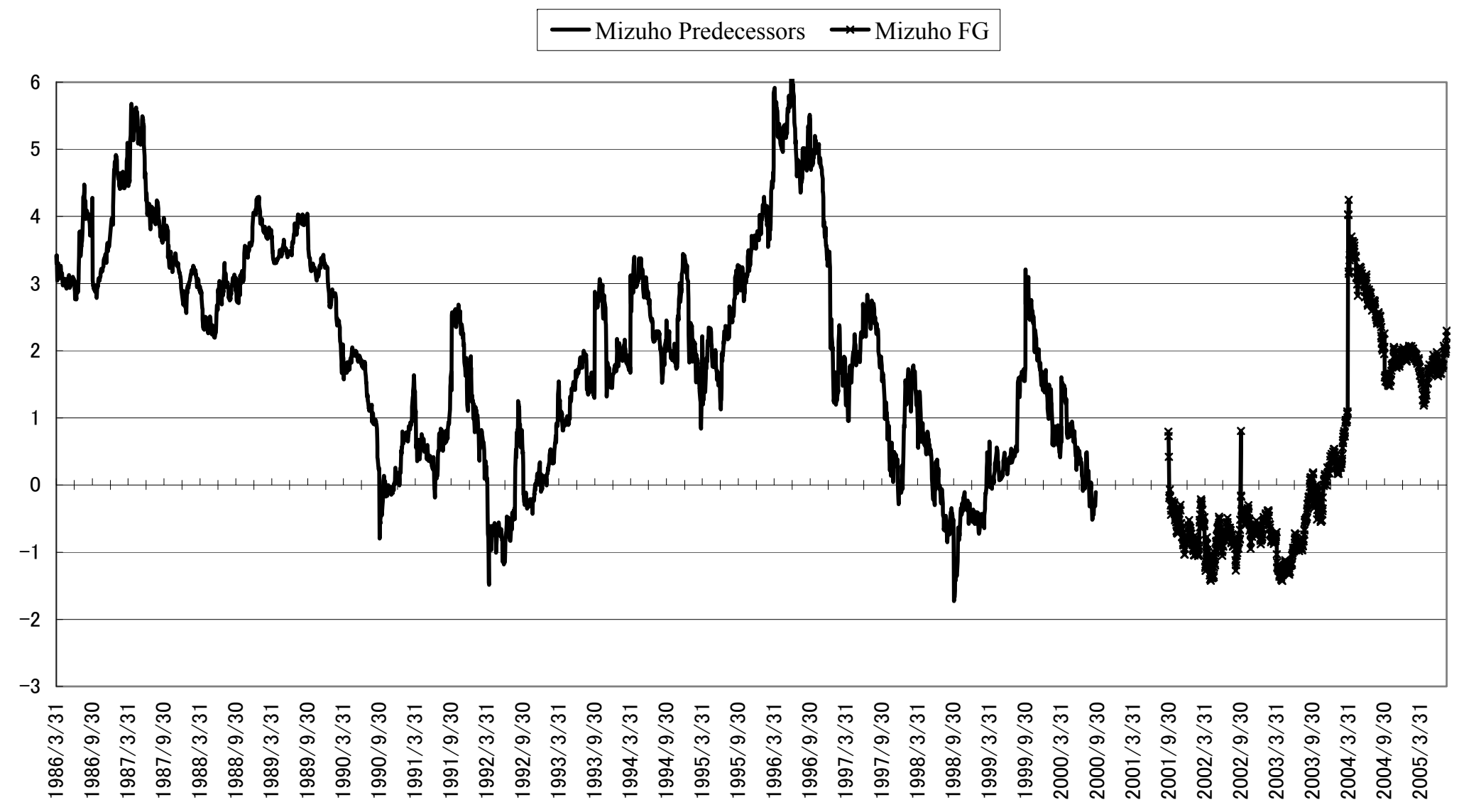


Figure 1-2 Mizuho FG DD from 2000

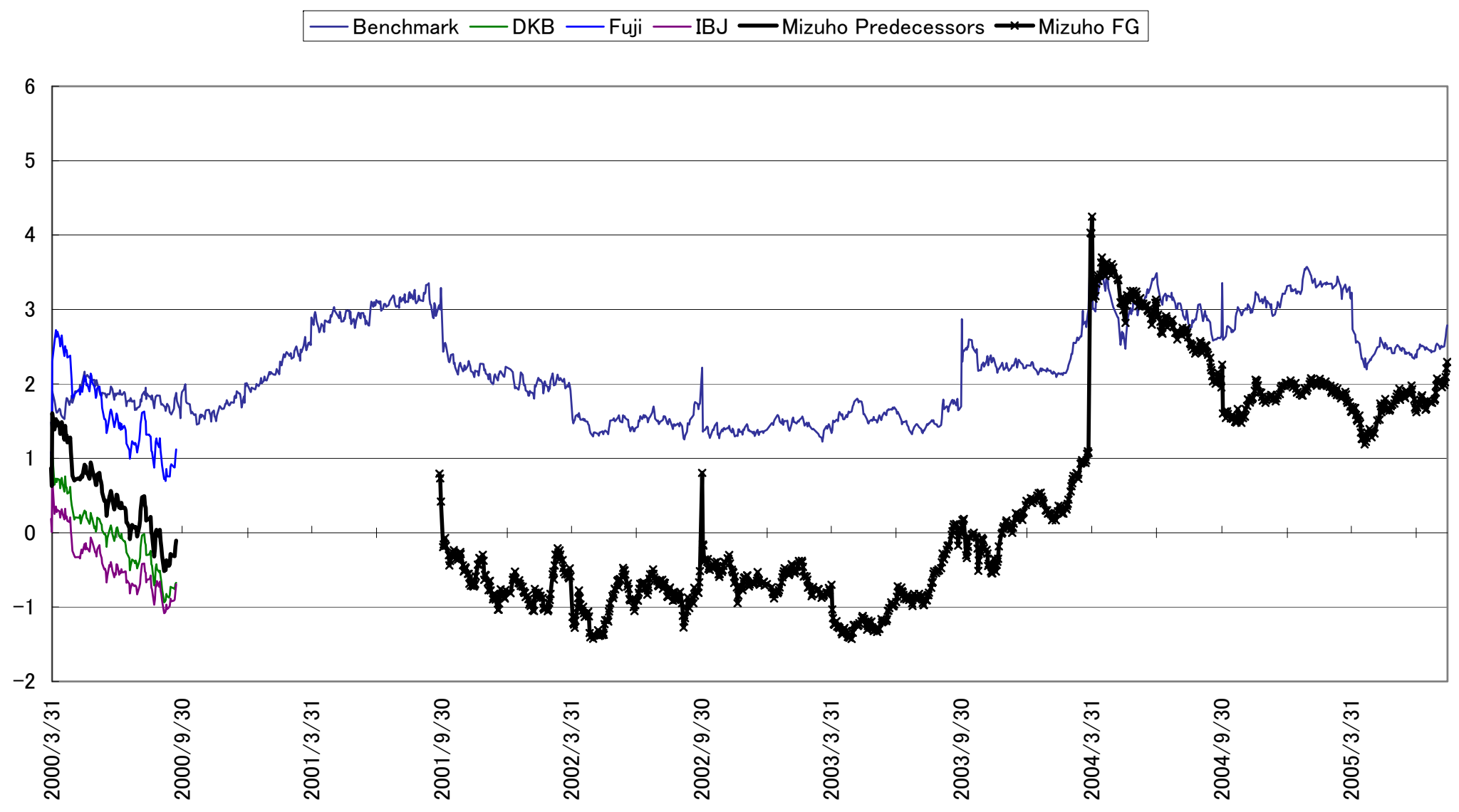


Figure 2-1 MTFG DD from 1985 to 2005

- BTM Predecessors - BTM $\rightarrow$ MTFG

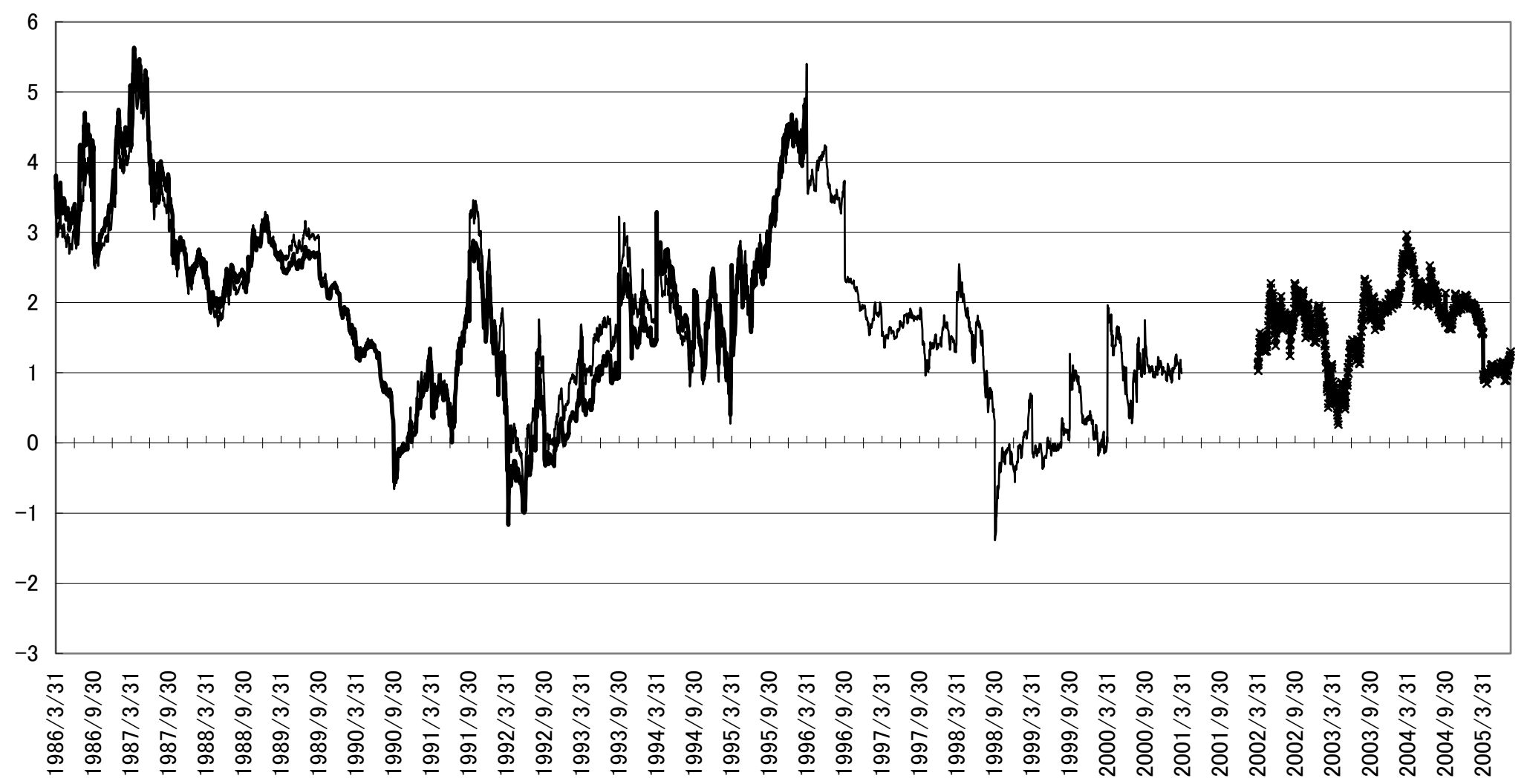


Figure 2-2 MTFG DD from 1995 to 1996

- Benchmark —BTM Predecessors —BTM

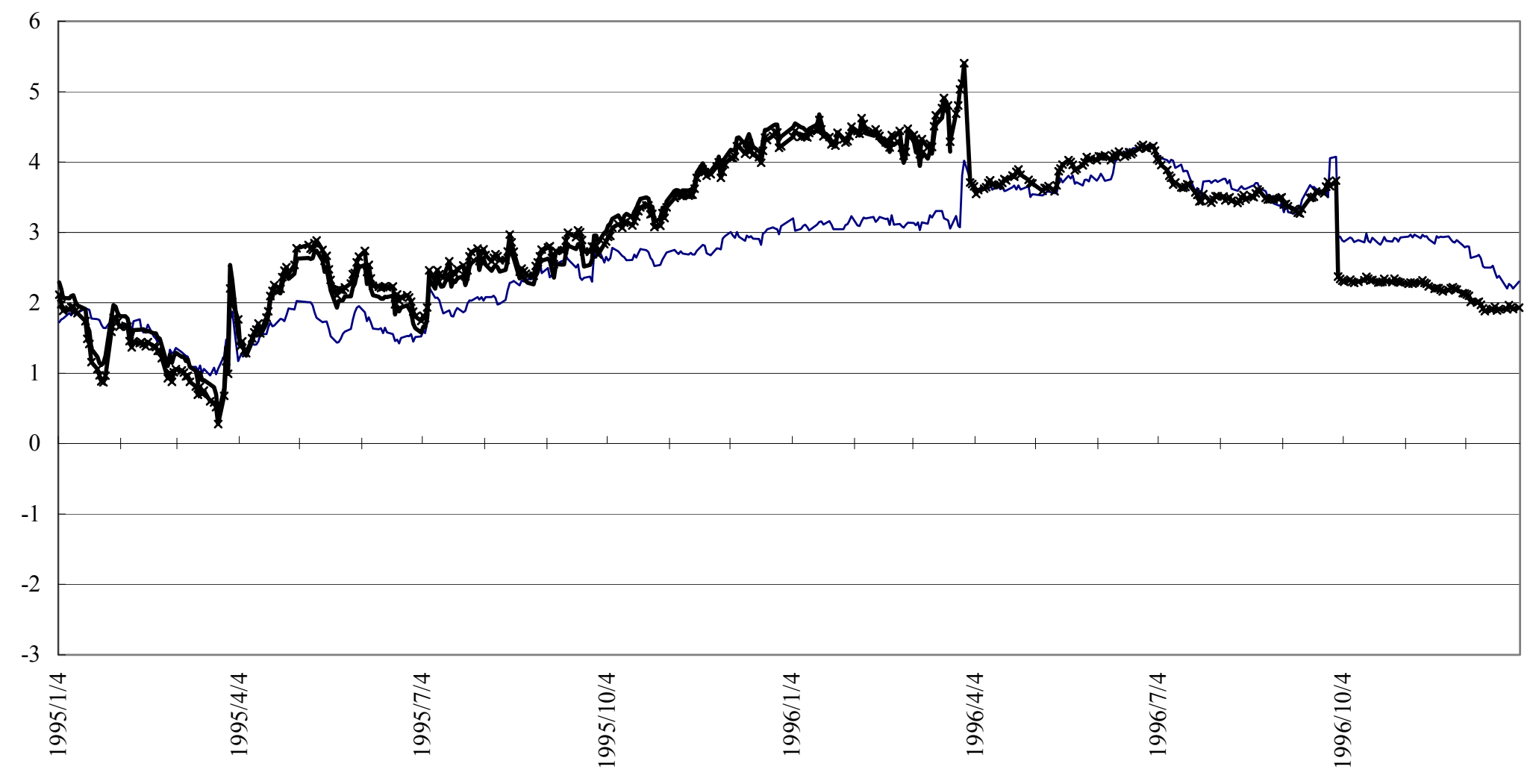

40 
Figure 2-3 MTFG DD from 2000

- Benchmark - BTM $\approx$ MTFG

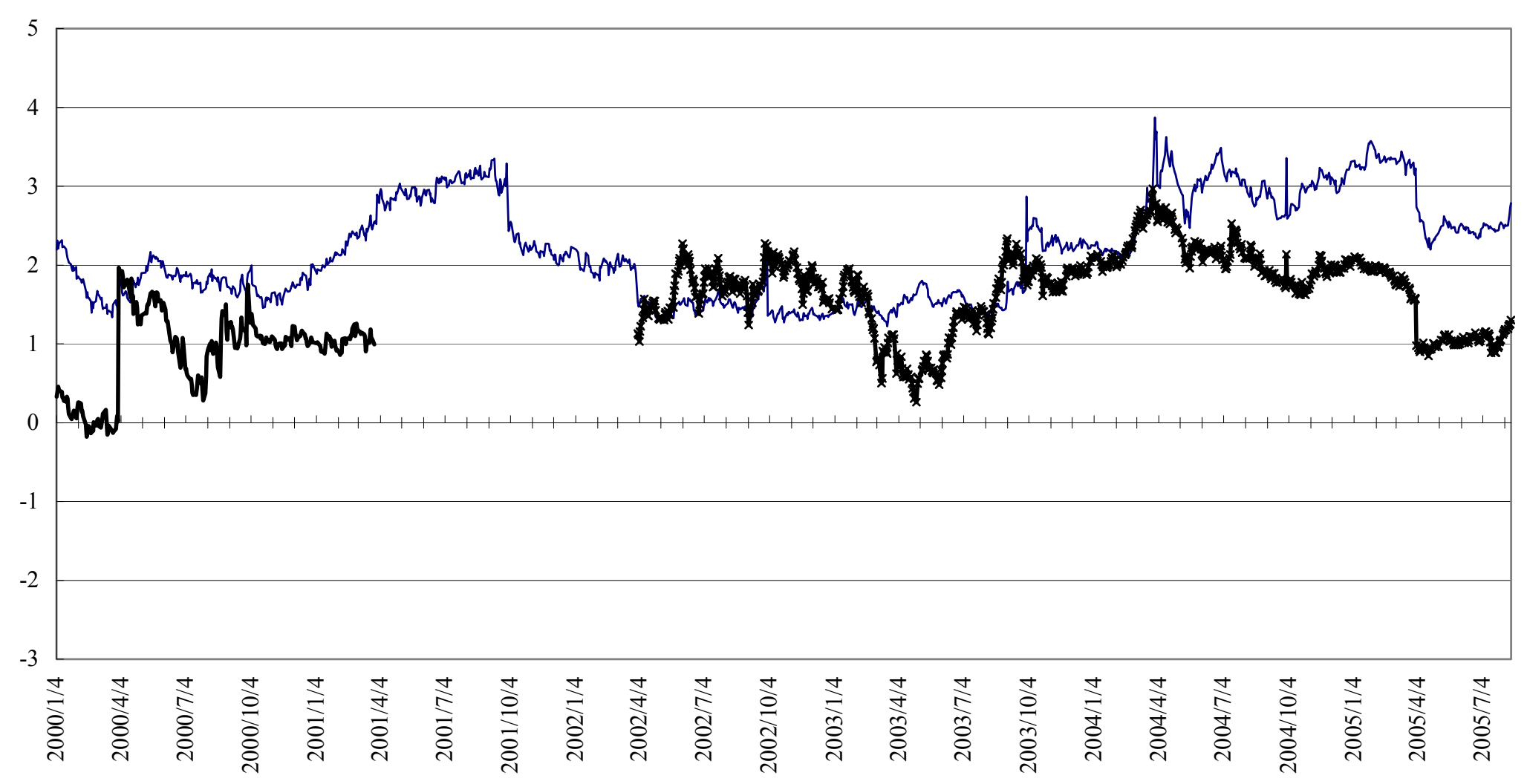


Figure 3-1 UFJHD DD from 1985 to 2005

—UFJ Predecessors —UFJHD

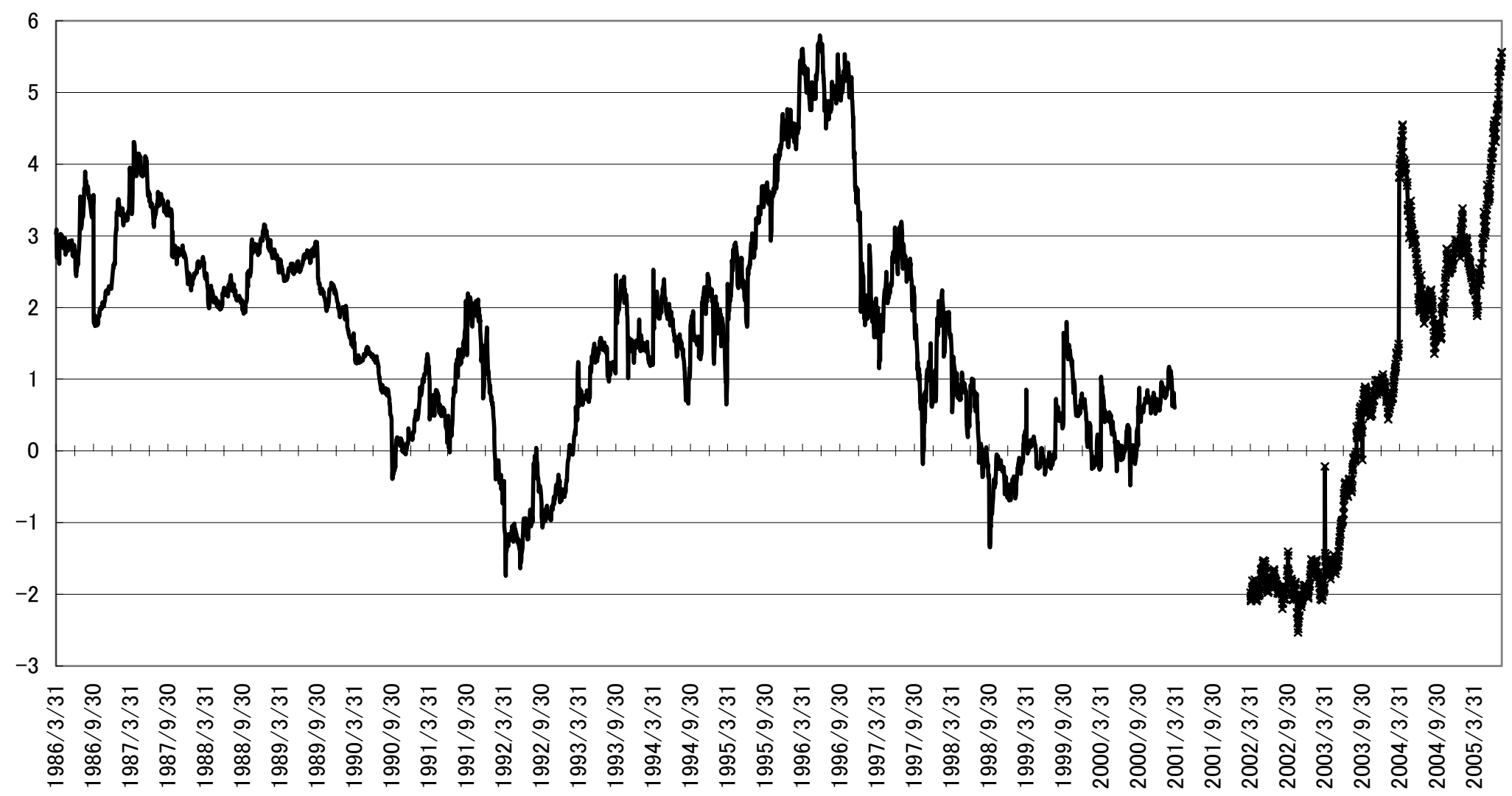


Figure 3-2 UFJ DD from 2000

- Benchmark - Sanwa $\rightarrow$ Tokai —UFJ Predecessors $\approx$ UFJHD

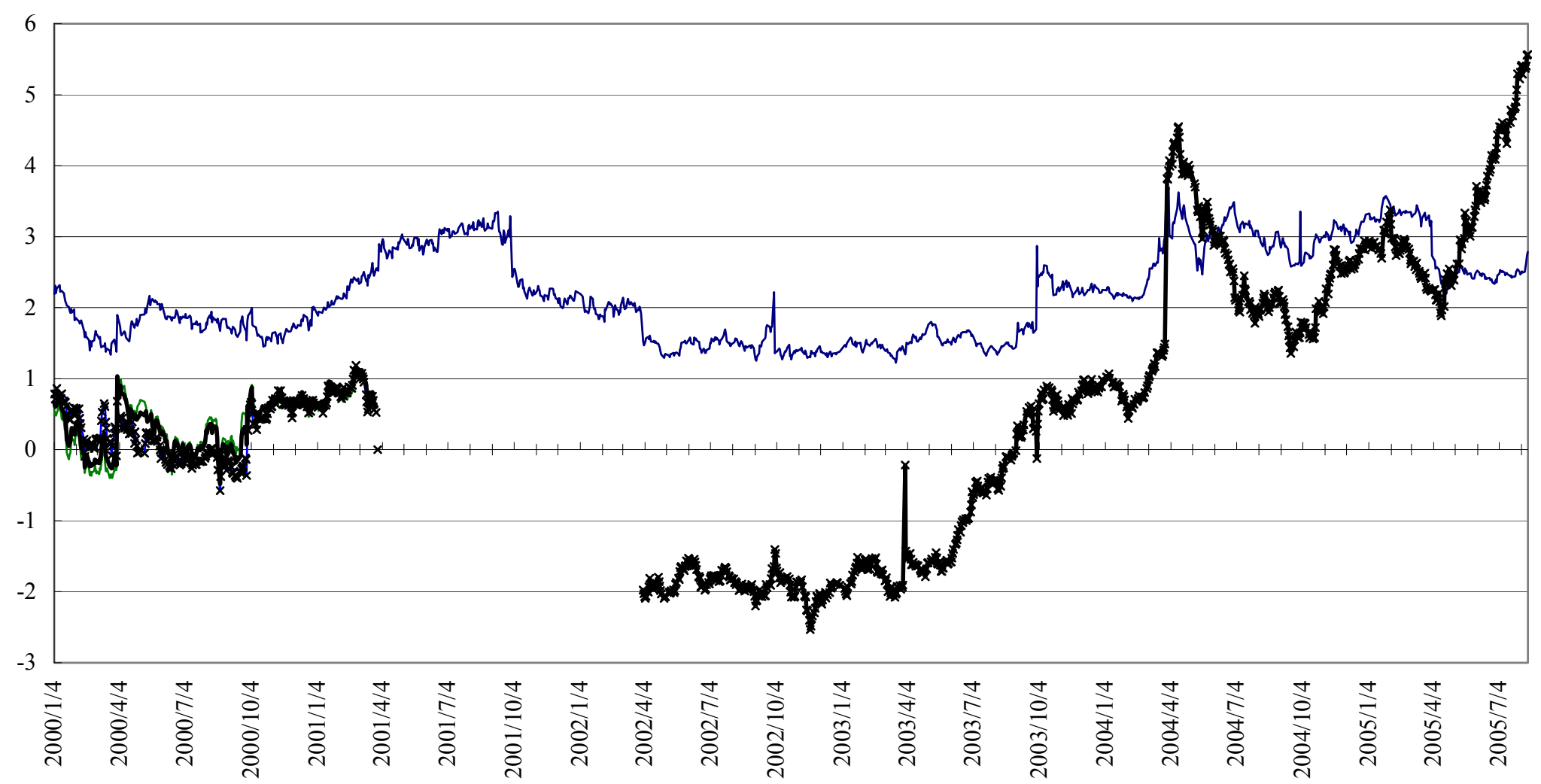


Figure 4 - 1 SMFG DD from 1985 to 2005

- SMBC Predecessors $\multimap$ SMBC

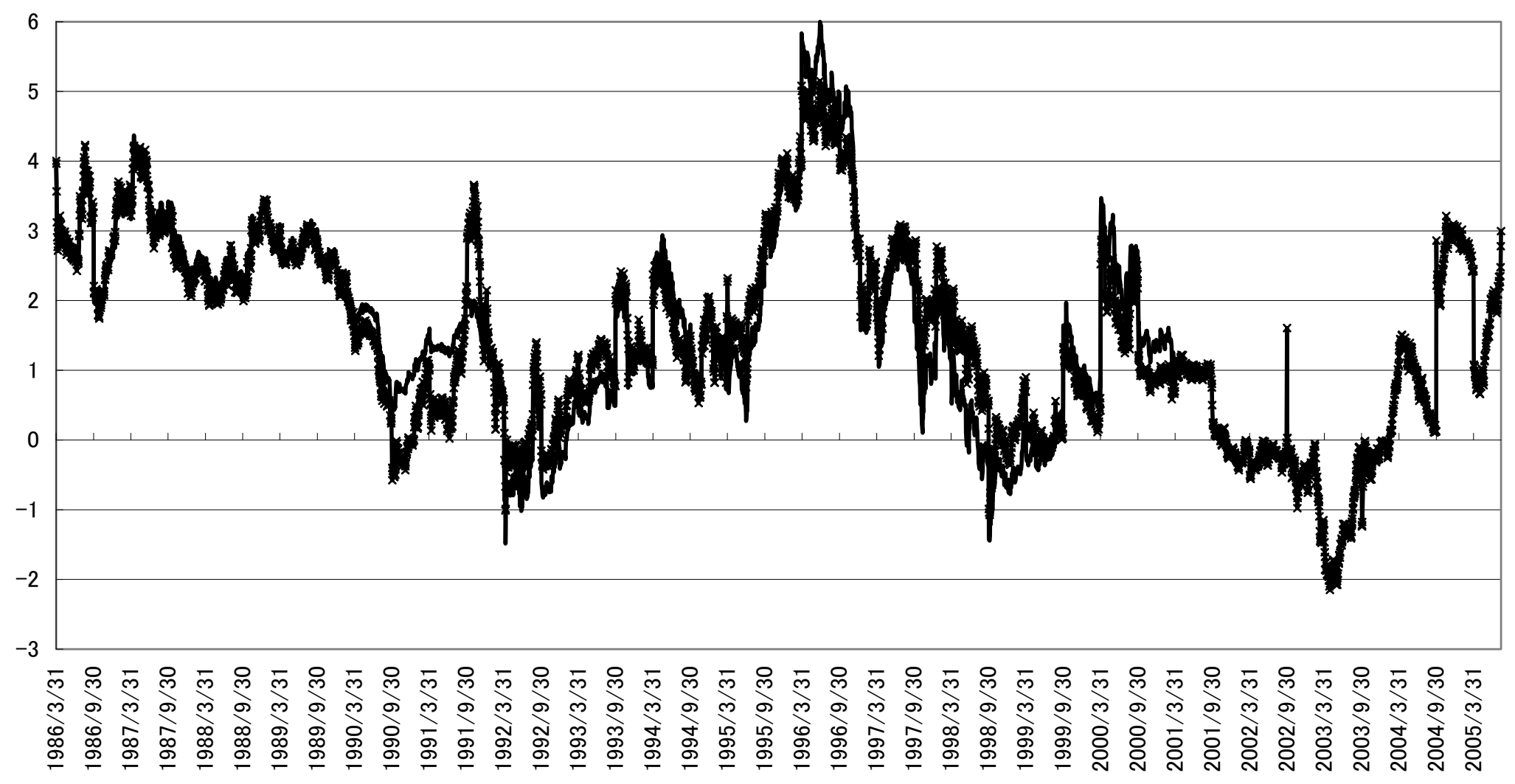


Figure 4-2 SMFG DD from 2000

- Benchmark $\longrightarrow$ SMBC Predecessors $\multimap$ SMBC

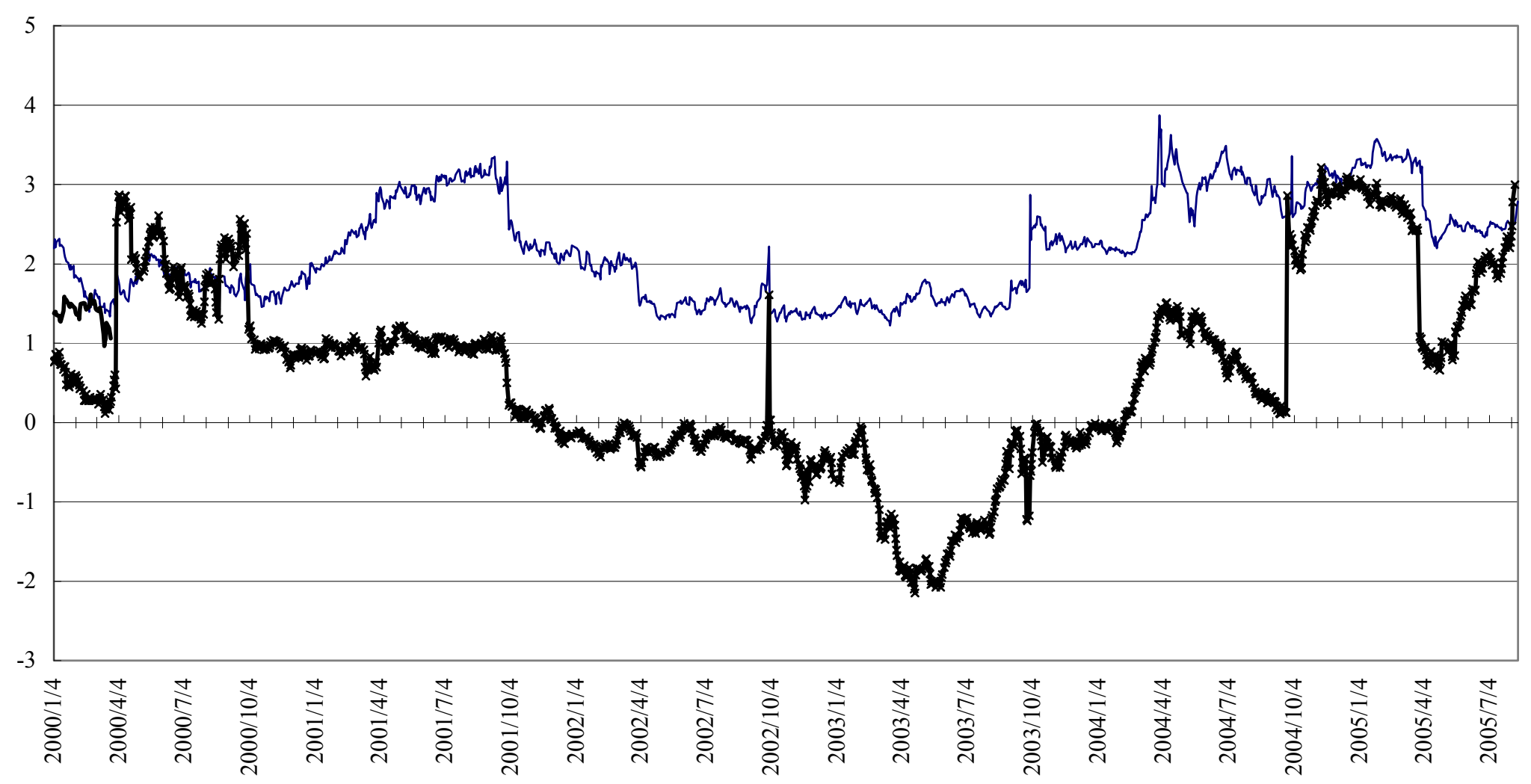


Table1:Mizuho Financial Group

Event window 500days

\begin{tabular}{|l|r|r|r|r|}
\hline \multirow{2}{*}{ DD average } & before merger & after merger \\
\cline { 2 - 5 } & $1998 / 9 / 10$ & $2000 / 9 / 21$ & $2001 / 9 / 26$ & $2003 / 10 / 7$ \\
\hline benchmark & \multicolumn{3}{|c|}{1.659} \\
\hline Mizuho & \multicolumn{3}{|c|}{0.517} & \multicolumn{2}{c}{-0.743} \\
\hline
\end{tabular}

Event window 250days

\begin{tabular}{|l|r|r|r|r|}
\hline \multirow{2}{*}{ DD average } & \multicolumn{2}{|l|}{ before merger } & after merger \\
\cline { 2 - 5 } & $1998 / 9 / 10$ & $2000 / 9 / 21$ & $2001 / 9 / 26$ & $2003 / 10 / 7$ \\
\hline benchmark & \multicolumn{3}{|c|}{1.428} & \multicolumn{2}{c|}{} \\
\hline Mizuho & \multicolumn{3}{|r}{-0.740} \\
\hline
\end{tabular}

Table2: Mitsubishi Tokyo Financial Group

Event 1: Event window 500days

\begin{tabular}{|c|c|c|c|c|}
\hline \multirow{2}{*}{ DD average } & \multicolumn{2}{|l|}{ before merger } & \multicolumn{2}{|l|}{ after merger } \\
\hline & $1994 / 3 / 16$ & $1996 / 3 / 22$ & $1996 / 3 / 26$ & $1998 / 4 / 3$ \\
\hline benchmark & & 2.039 & & 1.813 \\
\hline$\overline{\mathrm{BTM}}$ & & 2.452 & & 2.244 \\
\hline
\end{tabular}

Event window 250days

\begin{tabular}{|c|c|c|c|c|}
\hline \multirow{2}{*}{ DD average } & \multirow{2}{*}{\begin{tabular}{|c|} 
before merge \\
$1995 / 3 / 22$ \\
\end{tabular}} & & \multicolumn{2}{|l|}{ after merger } \\
\hline & & $1996 / 3 / 22$ & $1996 / 3 / 26$ & $1997 / 3 / 31$ \\
\hline benchmark & & 2.380 & & 2.963 \\
\hline BTM & & 3.058 & & 2.917 \\
\hline
\end{tabular}

Event 2:Event window 500days

\begin{tabular}{|l|r|r|r|r|}
\hline \multirow{2}{*}{ DD average } & \multicolumn{2}{|l|}{ before merger } & after merger \\
\cline { 2 - 5 } & $1999 / 3 / 15$ & $2001 / 3 / 26$ & $2002 / 4 / 1$ & $2004 / 4 / 8$ \\
\hline benchmark & \multicolumn{3}{|c}{1.972} & \multicolumn{2}{c}{1.721} \\
\hline MTFG & \multicolumn{3}{|r}{0.637} & \\
\hline
\end{tabular}

Event window 250days

\begin{tabular}{|c|c|c|c|c|}
\hline \multirow{2}{*}{ DD average } & \multicolumn{2}{|c|}{ before merger } & \multicolumn{2}{|l|}{ after merger } \\
\hline & $2000 / 3 / 22$ & $2001 / 3 / 26$ & $2002 / 4 / 1$ & $2003 / 4 / 4$ \\
\hline benchmark & & 2.070 & & 1.450 \\
\hline MTFG & & 0.192 & & 1.642 \\
\hline
\end{tabular}


Table3:UFJ Holdings

Event window 500days

\begin{tabular}{|c|c|c|c|c|}
\hline \multirow{2}{*}{ DD average } & before merge & & \multicolumn{2}{|l|}{ after merger } \\
\hline & $1999 / 3 / 15$ & $2001 / 3 / 26$ & $2002 / 4 / 1$ & $2004 / 4 / 8$ \\
\hline benchmark & & 1.972 & & 1.721 \\
\hline$\overline{\mathrm{UFJ}}$ & & 0.384 & & -0.857 \\
\hline
\end{tabular}

Event window 250days

\begin{tabular}{|c|c|c|c|c|}
\hline \multirow{2}{*}{ DD average } & \multicolumn{2}{|c|}{ before merger } & \multicolumn{2}{|l|}{ after merger } \\
\hline & $2000 / 3 / 22$ & $2001 / 3 / 26$ & $2002 / 4 / 1$ & $2003 / 4 / 4$ \\
\hline benchmark & & 1.871 & & 1.450 \\
\hline UFJ & & 0.454 & & -1.868 \\
\hline
\end{tabular}

Table4:Sumitomo Mitsui Financial Group

Event window 500days

\begin{tabular}{|c|c|c|c|c|}
\hline \multirow{2}{*}{ DD average } & before merger & & \multicolumn{2}{|l|}{ after merger } \\
\hline & $1999 / 3 / 15$ & $2001 / 3 / 26$ & $2001 / 3 / 27$ & $2003 / 4 / 7$ \\
\hline benchmark & & 1.972 & & 1.427 \\
\hline SMBC & & 1.201 & & -0.716 \\
\hline
\end{tabular}

Event window 250days

\begin{tabular}{|l|r|r|r|r|}
\hline \multirow{2}{*}{ DD average } & \multicolumn{2}{|l|}{ before merger } & after merger \\
\cline { 2 - 5 } & $2000 / 3 / 22$ & $2001 / 3 / 26$ & $2001 / 3 / 27$ & $2002 / 4 / 1$ \\
\hline benchmark & & 1.871 & & 2.562 \\
\hline SMBC & \multicolumn{3}{|r}{0.460} \\
\hline
\end{tabular}

\section{Table5: Paired t-test}

\begin{tabular}{|l|r|}
\hline Event window 250days \\
\hline Mizuho & $-31.66^{* * *}$ \\
\hline BTM event1 & $-86.86^{* * *}$ \\
\hline BTM event2 & $-25.60^{* * *}$ \\
\hline UFJ & $-70.44^{* * *}$ \\
\hline SMBC & $-50.16^{* * *}$ \\
\hline Event window 500days & \multicolumn{3}{l|}{} \\
\hline Mizuho & $-44.36^{* * *}$ \\
\hline BTM event1 & $-40.71^{* *}$ \\
\hline BTM event2 & $-9.10^{* * *}$ \\
\hline UFJ & $-24.29^{* * *}$ \\
\hline SMBC & $-27.56^{* * *}$ \\
\hline
\end{tabular}




\section{APPENDIX Tables}

\section{Appendix Table1: Short term and long term liablity of banks}

\begin{tabular}{|l|l|}
\hline Short term liability & Long term liability \\
\hline Deposits & Debentures \\
\hline Negotiable certificates of deposit & Straight bonds \\
\hline Call money & \\
\hline Payables under repurchase agreements & Convertible bonds \\
\hline Payables under securities lending transactions & Reserve for employee retirement benefit \\
\hline Bills sold & \\
\cline { 1 - 1 } Commercial papers & \\
\cline { 1 - 1 } Trading liabilities & \\
\cline { 1 - 1 } Borrowed money & \\
\cline { 1 - 1 } Foreign exchanges & \\
\cline { 1 - 1 } Short-term corporate bonds & \\
\cline { 1 - 1 } Other liabilities & \\
\cline { 1 - 1 } Reserve for employees' bonus & \\
\cline { 1 - 1 } Reserve for directors' bonus & \\
\cline { 1 - 1 } Other reserves & \\
\cline { 1 - 1 } Deserves under special laws & \\
\cline { 1 - 1 } Deferred tax liabilities & \\
\cline { 1 - 1 } Acceptances and guarantees &
\end{tabular}

Note1: Deposits include Current deposits, Ordinary deposits, Savings deposits, Deposits at notice, Time deposits and Installment savings.

Note2: Trading liabilities include Trading securities sold for short sales, Derivatives of trading securities, Securities related to trading transactions sold for short sales, Derivatives of securities related to trading transactions and Trading-related financial derivatives. 
Appendix Table2: Mizuho Financial Group

\begin{tabular}{|c|c|c|c|}
\hline Name & DD period & Stock price period & Financial statement period \\
\hline DKB & $\begin{array}{l}\text { March 31, } 1986 \text { to September } \\
21,2000\end{array}$ & $\begin{array}{l}\text { April 1, } 1985 \text { to September } \\
21,2000\end{array}$ & \begin{tabular}{|l} 
DKB Unconsolidated \\
March 1985 to March 2000
\end{tabular} \\
\hline Fuji & $\begin{array}{l}\text { March 31, } 1986 \text { to September } \\
21,2000\end{array}$ & $\begin{array}{l}\text { April } 1,1985 \text { to September } \\
21,2000\end{array}$ & $\begin{array}{l}\text { Fuji Unconsolidated } \\
\text { March } 1985 \text { to March } 2000\end{array}$ \\
\hline IBJ & $\begin{array}{l}\text { March } 31,1986 \text { to September } \\
21,2000\end{array}$ & $\begin{array}{l}\text { April 1, } 1985 \text { to September } \\
21,2000\end{array}$ & $\begin{array}{l}\text { IBJ Unconsolidated } \\
\text { March } 1985 \text { to March } 2000\end{array}$ \\
\hline $\begin{array}{l}\text { Mizuho Predecessors } \\
(\mathrm{DKB}+\mathrm{Fuji}+\mathrm{IBJ})\end{array}$ & $\begin{array}{l}\text { March 31, } 1986 \text { to September } \\
21,2000\end{array}$ & $\begin{array}{l}\text { April } 1,1985 \text { to September } \\
21,2000\end{array}$ & $\begin{array}{l}\text { (DKB+Fuji+IBJ) } \\
\text { Unconsolidated } \\
\text { March } 1985 \text { to March } 2000\end{array}$ \\
\hline Mizuho FG & $\begin{array}{l}\text { September 26, } 2001 \text { to August } \\
12,2005 \text {. DD is not available } \\
\text { from March 6, } 2003 \text { to March } \\
11,2003 \text { due to the structural } \\
\text { change from Mizuho HDs to } \\
\text { Mizuho FG. }\end{array}$ & $\begin{array}{l}\text { September 28, } 2000 \text { to } \\
\text { August } 12,2005\end{array}$ & $\begin{array}{l}\text { (Mizuho+Mizuho Corporate) } \\
\text { Unconsolidated } \\
\text { March } 2000 \text { to March } 2005\end{array}$ \\
\hline
\end{tabular}

\section{Appendix Table 3: Mitsubishi Tokyo Financial Group}

\begin{tabular}{|l|l|l|l|}
\hline Name & DD period & Stock price period & Financial statement period \\
\hline BTM & $\begin{array}{l}\text { March 31, 1986 to March 21, } \\
2001\end{array}$ & $\begin{array}{l}\text { April 1, 1985 to March 21, } \\
2001\end{array}$ & $\begin{array}{l}\text { BTM Unconsolidated } \\
\text { March 1985 to March 2001 }\end{array}$ \\
\hline Tokyo & $\begin{array}{l}\text { March 31,1986 to March 21, } \\
2001\end{array}$ & $\begin{array}{l}\text { April 1, 1985 to March 21, } \\
2001\end{array}$ & $\begin{array}{l}\text { Tokyo Unconsolidated } \\
\text { March 1985 to March 1996 }\end{array}$ \\
\hline $\begin{array}{l}\text { MTFG Predecessors } \\
\text { Mitsubishi+Tokyo) }\end{array}$ & $\begin{array}{l}\text { March 31,1986 to March 21, } \\
2001\end{array}$ & $\begin{array}{l}\text { April 1, 1985 to March 21, } \\
2001\end{array}$ & $\begin{array}{l}\text { Mitsubishi+Tokyo) } \\
\text { Unconsolidated } \\
\text { March 1985 to March 1996 }\end{array}$ \\
\hline MTFG & 2005 & $\begin{array}{l}\text { April 2001 to August 12, } \\
\text { April 1, 2001 to August 12, }\end{array}$ & $\begin{array}{l}\text { MTFG Consolidated } \\
\text { 2005. Financial statement of } \\
\text { March 2001 is not available } \\
\text { due to the consolidation. }\end{array}$ \\
\hline
\end{tabular}


Appendix Table 4: UFJ Holdings

\begin{tabular}{|c|c|c|c|}
\hline Name & DD period & Stock price period & Financial statement period \\
\hline Sanwa & $\begin{array}{l}\text { March 31, } 1986 \text { to March 26, } \\
2001\end{array}$ & $\begin{array}{l}\text { April 1, } 1985 \text { to March 26, } \\
2001\end{array}$ & $\begin{array}{l}\text { Sanwa Unconsolidated } \\
\text { March } 1985 \text { to March } 2001\end{array}$ \\
\hline Tokai & $\begin{array}{l}\text { March 31, } 1986 \text { to March 26, } \\
2001\end{array}$ & $\begin{array}{l}\text { April 1, } 1985 \text { to March 26, } \\
2001\end{array}$ & $\begin{array}{l}\text { Tokai Unconsolidated } \\
\text { March } 1985 \text { to March } 2001\end{array}$ \\
\hline $\begin{array}{l}\text { UFJ Predecessors } \\
\text { (Sanwa+Tokai) }\end{array}$ & $\begin{array}{l}\text { March 31, } 1986 \text { to March 26, } \\
2001\end{array}$ & $\begin{array}{l}\text { April 1, } 1985 \text { to March 26, } \\
2001\end{array}$ & $\begin{array}{l}\text { (Sanwa+Tokai) } \\
\text { Unconsolidated } \\
\text { March } 1985 \text { to March } 2001\end{array}$ \\
\hline UFJHD & $\begin{array}{l}\text { April 1, } 2001 \text { to August 12, } \\
2005\end{array}$ & $\begin{array}{l}\text { April 1, } 2001 \text { to August 12, } \\
2005\end{array}$ & $\begin{array}{l}\text { UFJHD Consolidated } \\
\text { September 2001 to March } \\
2005 \text { Financial statement of } \\
\text { March } 2001 \text { is not available } \\
\text { due to the consolidation. }\end{array}$ \\
\hline
\end{tabular}

\section{Appendix Table 5: Sumitomo Mitsui Financial Group}

\begin{tabular}{|c|c|c|c|}
\hline Name & DD period & Stock price period & Financial statement period \\
\hline $\begin{array}{l}\text { Sumitomo ( later SMBC then } \\
\text { SMFG) }\end{array}$ & $\begin{array}{l}\text { March 31, } 1986 \text { to August 12, } \\
2005 \\
\text { November 26, } 2002 \text { to } \\
\text { December 1, 2002 DD is not } \\
\text { availahle as the stock nrice is }\end{array}$ & $\begin{array}{l}\text { April 1, 1985 to November } \\
25.2002 \\
\text { and December 2, } 2002 \text { to } \\
\text { August } 12,2005\end{array}$ & $\begin{array}{l}\text { SMBC(N0070010) } \\
\text { Unconsolidated } \\
\text { March } 1985 \text { to September } \\
2002 \\
\text { SMFG(N0070174) } \\
\text { Unconsolidated } \\
\text { March 2003 to March } 2005 \\
\text { Financial statement of March } \\
2001 \text { is not available due to } \\
\text { the consolidation. }\end{array}$ \\
\hline Sakura & $\begin{array}{l}\text { March } 311986 \text { to March } 26 \\
2001\end{array}$ & $\begin{array}{llll}\text { April } 11985 & \text { to March } 26 \\
2001 & & & \end{array}$ & $\begin{array}{l}\text { Sakura Unconsolidated } \\
\text { March } 1985 \text { to March } 2001\end{array}$ \\
\hline TaiyoKobe & $\begin{array}{l}\text { March } 311986 \text { to March } 23 \\
1990\end{array}$ & $\begin{array}{lllll}\text { April } 1 & 1985 & \text { to } \text { March } 23 \\
1990 & & & \end{array}$ & $\begin{array}{l}\text { Unconsolidated } \\
\text { March } 1985 \text { to March } 1990\end{array}$ \\
\hline $\begin{array}{l}\text { SMBC Predecessors } \\
\text { (Sumitomo+Sakura) }\end{array}$ & $\begin{array}{l}\text { March } 311986 \text { to March } 26 \\
2001\end{array}$ & $\begin{array}{l}\text { April } 11985 \text { to March } 26 \\
2001\end{array}$ & $\begin{array}{l}\text { (Sumitomo+Sakura) } \\
\text { Unconsolidated } \\
1985 \text { to March } 2001\end{array}$ \\
\hline
\end{tabular}

